\title{
A Fourier transform infrared trace gas and isotope analyser for atmospheric applications
}

\author{
D. W. T. Griffith ${ }^{1}$, N. M. Deutscher ${ }^{1, *}$, C. Caldow ${ }^{1}$, G. Kettlewell ${ }^{1}$, M. Riggenbach ${ }^{1}$, and S. Hammer ${ }^{2}$ \\ ${ }^{1}$ University of Wollongong, Wollongong NSW 2522, Australia \\ ${ }^{2}$ University of Heidelberg, Institute of Environmental Physics, Heidelberg, Germany \\ * now at: University of Bremen, Institute of Environmental Physics, Bremen, Germany
}

Correspondence to: D. W. T. Griffith (griffith@uow.edu.au)

Received: 3 May 2012 - Published in Atmos. Meas. Tech. Discuss.: 29 May 2012

Revised: 18 September 2012 - Accepted: 19 September 2012 - Published: 24 October 2012

\begin{abstract}
Concern in recent decades about human impacts on Earth's climate has led to the need for improved and expanded measurement capabilities of greenhouse gases in the atmosphere. In this paper we describe in detail an in situ trace gas analyser based on Fourier Transform Infrared (FTIR) spectroscopy that is capable of simultaneous and continuous measurements of carbon dioxide $\left(\mathrm{CO}_{2}\right)$, methane $\left(\mathrm{CH}_{4}\right)$, carbon monoxide $(\mathrm{CO})$, nitrous oxide $\left(\mathrm{N}_{2} \mathrm{O}\right)$ and ${ }^{13} \mathrm{C}$ in $\mathrm{CO}_{2}$ in air with high precision. High accuracy is established by reference to measurements of standard reference gases. Stable water isotopes can also be measured in undried airstreams. The analyser is automated and allows unattended operation with minimal operator intervention. Precision and accuracy meet and exceed the compatibility targets set by the World Meteorological Organisation - Global Atmosphere Watch for baseline measurements in the unpolluted troposphere for all species except ${ }^{13} \mathrm{C}$ in $\mathrm{CO}_{2}$.

The analyser is mobile and well suited to fixed sites, tower measurements, mobile platforms and campaign-based measurements. The isotopic specificity of the opticallybased technique and analysis allows its application in isotopic tracer experiments, for example in tracing variations of ${ }^{13} \mathrm{C}$ in $\mathrm{CO}_{2}$ and ${ }^{15} \mathrm{~N}$ in $\mathrm{N}_{2} \mathrm{O}$. We review a number of applications illustrating use of the analyser in clean air monitoring, micrometeorological flux and tower measurements, mobile measurements on a train, and soil flux chamber measurements.
\end{abstract}

\section{Introduction}

Growing concern in recent decades about human impacts on Earth's climate has led to the need for improved understanding of the global carbon cycle and the sources and sinks of greenhouse gases in the atmosphere. The Fourth Assessment Report of the Intergovernmental Panel on Climate Change (IPCC, 2007) provides the most recent and extensive overview of the physical basis of human-induced climate change. Carbon dioxide $\left(\mathrm{CO}_{2}\right)$ and methane $\left(\mathrm{CH}_{4}\right)$ are the most important long-lived anthropogenic greenhouse gases (GHGs), accounting for $64 \%$ and $18 \%$, respectively, of human-induced radiative forcing since the pre-industrial era (Hofmann et al., 2006, for update see http://www.esrl. noaa.gov/gmd/aggi/). Nitrous oxide $\left(\mathrm{N}_{2} \mathrm{O}\right)$ is the third most important greenhouse gas with a $6 \%$ contribution that is becoming more important as the now-restricted chlorofluorocarbons decay in the atmosphere (Ravishankara et al., 2009). Major sources of anthropogenic $\mathrm{CO}_{2}$ increases are fossil fuel combustion for energy; for $\mathrm{CH}_{4}$ they are increased wetlands and agricultural livestock emissions; and for $\mathrm{N}_{2} \mathrm{O}$ the increased use of nitrogeneous fertilisers in agriculture. $\mathrm{CO}_{2}$ emissions are partially taken up and recycled by the oceans, land and the biosphere, but approximately half of fossil fuel $\mathrm{CO}_{2}$ accumulates in the atmosphere. $\mathrm{CH}_{4}$ and $\mathrm{N}_{2} \mathrm{O}$ are ultimately chemically destroyed in the atmosphere, but increasing sources also mean that their atmospheric abundances are increasing (IPCC, 2007).

Measurements of greenhouse gases in the atmosphere provide the fundamental data on which our understanding is based. In situ measurements at the local or ecosystem level 
lead to "bottom-up" detailed understanding of the individual processes and magnitudes of GHG exchanges, but are necessarily sparse. They require significant up-scaling and extrapolation if they are to be used in global-scale models of GHG source-sink distributions and inventories. In the alternative "top-down" approach, time series of in situ and remote sensing measurements are combined with inverse models and atmospheric transport to infer source-sink distributions at global scales, but here the problem is mathematically illposed, and uncertainties are dominated by the sparseness of the available measurements. Both top-down and bottom-up approaches benefit from new techniques which can increase the density and accuracy of available measurements. In particular, the extension of measurements from occasional, often flask-based sampling programmes to continuous measurements near the ground, on tall towers, and from satellites is highly desirable. Continuous measurements resolve variability on diurnal and synoptic timescales, which is becoming increasingly accessible to high resolution modeling. However the accuracy requirements are stringent - the World Meteorological Organisation's Global Atmosphere Watch (GAW) specifies the required inter-station compatibility and lack of bias required for measurements to improve understanding of global greenhouse gas cycling. These requirements and approximate global mean atmospheric mole fractions (2010) are listed in Table 1 (GAW, 2011).

Regular atmospheric GHG measurements effectively began in the International Geophysical Year of 1957 with the establishment of $\mathrm{CO}_{2}$ measurements by nondispersive infrared (NDIR) spectroscopy at Mauna Loa in Hawaii by C. D. Keeling (Keeling et al., 1995), and are now continuous at several global sites (e.g. Francey et al., 2010; Steele et al., 2011, see also http://www.esrl.noaa.gov/gmd/). For other species, high accuracy greenhouse gas measurements have been dominated by gas chromatography (GC) techniques using various detectors. GC requires frequent calibration but can be automated and is commonly used to provide pseudocontinuous spot-measurements for most species in many stations and networks (see for example van der Laan et al., 2009; Vermeulen et al., 2011; Popa et al., 2010; Prinn et al., 2000; Langenfelds et al., 2011).

Optical techniques based on the absorption or emission of radiation are well suited to continuous measurements and have a robust physical basis for calibration. Recent advances in laser-based techniques have achieved the required precision in many cases and several instruments have become commercially available. Lasers are inherently singlewavelength devices that can be scanned over single absorption lines in a narrow wavelength interval. They are typically restricted to only one or two species, but high brightness of the laser source leads to low noise and high precision measurements. Earlier instruments used liquid nitrogen-cooled lead-salt mid-infrared lasers (MIR, $\lambda>2.0 \mu \mathrm{m}$ ), but these have been largely supplanted by cheaper, mass produced and readily available near-infrared lasers (NIR, $\lambda \sim 0.7-2.0 \mu \mathrm{m}$ )

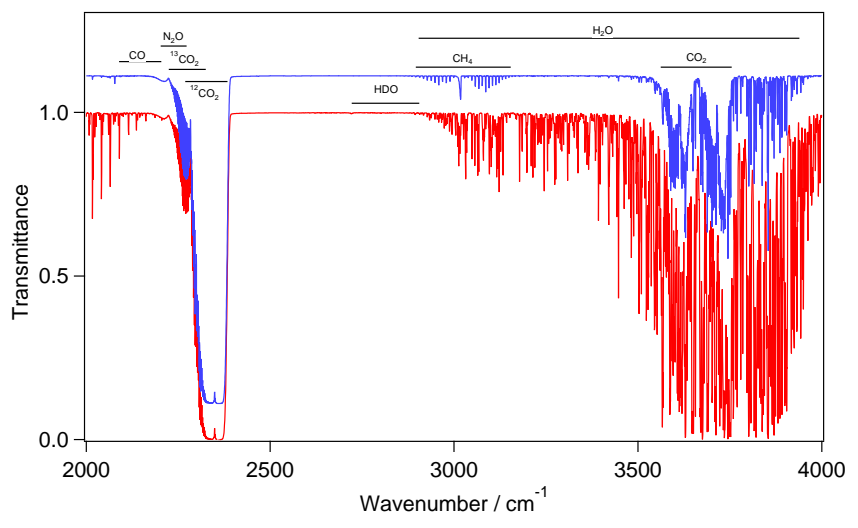

Fig. 1. The mid-infrared absorption spectrum of clean air in a $24 \mathrm{~m}$ cell. Red: undried air, blue: dried air. Positions of main absorption bands of target gases $\mathrm{CO}_{2}, \mathrm{CH}_{4}, \mathrm{CO}$ and $\mathrm{N}_{2} \mathrm{O}$ are shown. More detail of individual regions is shown in Fig. 3.

operating near room temperature. While the NIR lasers are relatively cheap and freely available, absorption bands in the NIR are generally overtone and combination bands which are weak absorbers compared to the fundamental vibration bands in the MIR. The weak absorption cancels some of the advantage of high brightness and low noise, and long absorption paths are required to obtain the desired precision. Most recently, quantum cascade lasers operating near room temperature at MIR wavelengths have been developed, and these are becoming commercially available (e.g. Tuzson et al., 2011).

Fourier Transform InfraRed (FTIR) spectroscopy offers an alternative infrared optical technique to laser spectroscopy. FTIR uses broadband infrared radiation from a blackbody light source that covers the entire infrared spectrum simultaneously. In FTIR spectroscopy, the source radiation is modulated by a Michelson interferometer and all optical frequencies are recorded simultaneously in the measured interferogram (Davis et al., 2001; Griffiths and de Haseth, 2007). A mathematical Fourier transform retrieves the spectrum (intensity vs. frequency) from the interferogram. Compared to laser sources the blackbody source is less bright, but this disadvantage is largely offset by the multiplex advantage of measuring the whole spectrum simultaneously, and operation in the MIR region where absorption bands are strong compared to the NIR. The result is precision similar to or better than NIR-laser based instruments, but with the ability to determine several species, including isotopologues, simultaneously from the same measured spectrum.

Figure 1 shows the mid infrared spectra of whole clean air, dried and undried, in a $24 \mathrm{~m}$ path absorption cell as recorded with the analyser described in this paper. The target gases, carbon dioxide $\left(\mathrm{CO}_{2}\right)$, methane $\left(\mathrm{CH}_{4}\right)$, nitrous oxide $\left(\mathrm{N}_{2} \mathrm{O}\right)$, carbon monoxide $(\mathrm{CO})$, and water vapour $\left(\mathrm{H}_{2} \mathrm{O}\right)$ have absorption bands in this region. Infrared absorption frequencies depend on the atomic masses, and in the case of ${ }^{13} \mathrm{CO}_{2}$ the $v_{3}$ stretching vibration is shifted $66 \mathrm{~cm}^{-1}$ from the parent 
Table 1. Global mean mole fractions, GAW measurement compatibility requirements, and FTIR analyser measurement precision (Allan deviation for 1- and 10-min averaging times) for target trace gases.

\begin{tabular}{llrrr}
\hline & $\begin{array}{l}\text { Approximate global } \\
\text { mean mole fraction, 2010 } \\
\text { Species }\end{array}$ & $\begin{array}{l}\text { GAW recommended } \\
\text { compatibility target }\end{array}$ & \multicolumn{2}{c}{$\begin{array}{c}\text { FTIR measurement } \\
\text { repeatability }\end{array}$} \\
\cline { 3 - 5 } & & & $1 \mathrm{~min}$ & $10 \mathrm{~min}$ \\
\hline $\mathrm{CO}_{2} / \mu \mathrm{mol} \mathrm{mol}^{-1}$ & 389 & $0.1(\mathrm{NH}) 0.05(\mathrm{SH})$ & 0.02 & 0.01 \\
$\mathrm{CH}_{4} / \mathrm{nmol} \mathrm{mol}^{-1}$ & 1808 & 2 & 0.2 & 0.06 \\
$\mathrm{~N}_{2} \mathrm{O} / \mathrm{nmol} \mathrm{mol}^{-1}$ & 323 & 0.1 & 0.1 & 0.03 \\
$\mathrm{CO} / \mathrm{nmol} \mathrm{mol}^{-1}$ & $100(\mathrm{NH}) 50(\mathrm{SH})$ & 2 & 0.2 & 0.08 \\
$\delta^{13} \mathrm{C}_{-} \mathrm{CO}_{2} / \% 0$ & -8.2 & 0.01 & 0.07 & 0.02 \\
\hline
\end{tabular}

${ }^{12} \mathrm{CO}_{2}$ band, which allows independent determination of ${ }^{13} \mathrm{C}$ in $\mathrm{CO}_{2}$ with a low resolution FTIR spectrometer. $\mathrm{H}^{2} \mathrm{HO}$ (HDO) absorption is also well separated from that of $\mathrm{H}_{2} \mathrm{O}$ and allows measurements of H/D fractionation (Parkes et al., 2012). Quantitative analysis of broad regions of the spectrum (typically $100-200 \mathrm{~cm}^{-1}$ wide) including whole absorption bands of the molecules of interest provides the concentrations of the target species. The spectral information from many ro-vibronic lines is included in each analysis, enhancing the information content of the measurement compared to narrow-band, single line laser methods, thus leading to high measurement precision and stability.

In this paper we describe the construction, performance and selected applications of a high precision trace gas analyser based on low resolution Fourier Transform Infrared (FTIR) spectrometry. The FTIR spectrometer is coupled to a multi-pass (White) cell and a gas sampling manifold and is principally intended for in situ sampling and analysis of ambient air. The analyser is fully automated and provides realtime concentration or mole fraction measurements of target gases including $\mathrm{CO}_{2}, \mathrm{CO}, \mathrm{CH}_{4}, \mathrm{~N}_{2} \mathrm{O}, \mathrm{H}_{2} \mathrm{O}$ and the isotopologues ${ }^{13} \mathrm{CO}_{2}, \mathrm{HDO}$ and $\mathrm{H}_{2}^{18} \mathrm{O}$. The analyser is an extension of earlier work (Esler et al., 2000a, b) and incorporates significant improvements in usability and performance. Parkes et al. (2012) describe optimisation of the analyser for stable water isotope measurements (Parkes et al., 2012).

\section{Description of the analyser}

\subsection{Hardware}

The FTIR spectrometer is a Bruker IRcube, a modular unit built around a frictionless flex-pivot interferometer with $1 \mathrm{~cm}^{-1}$ resolution $\left(0.5 \mathrm{~cm}^{-1}\right.$ optional $)$ and $25 \mathrm{~mm}$ beam diameter, globar source and $\mathrm{CaF}_{2}$ beamsplitter. The modulated exit beam is coupled to a multipass White cell by transfer optics consisting of two flat mirrors. The White cell is a permanently aligned glass cell, f-matched to the FTIR beam with a total folded path of $24 \mathrm{~m}$ and volume 3.51 . The beam exiting the White cell is directed back into the IRcube and fo-

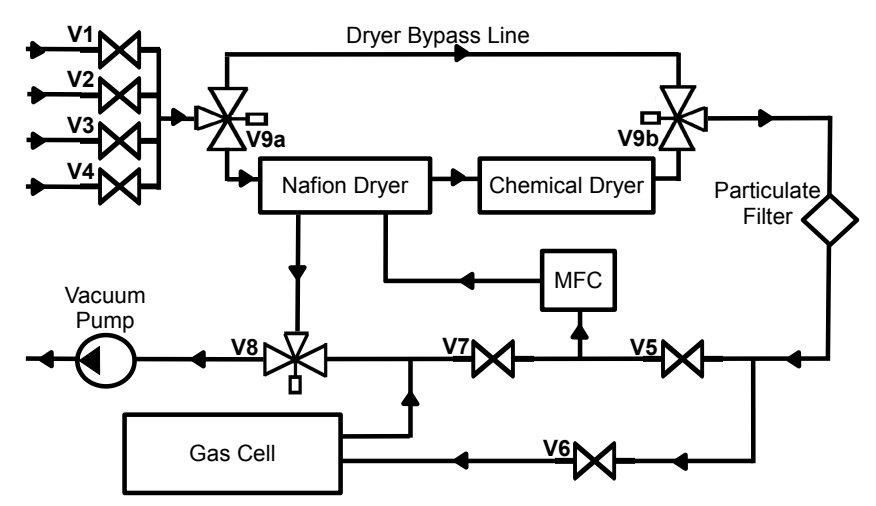

Fig. 2. Schematic view of the sampling gas manifold. For valve functions see text.

cussed onto a $1 \mathrm{~mm}$ diameter thermoelectrically-cooled Mercury Cadmium Telluride (MCT) detector with peak detectivity at $2000 \mathrm{~cm}^{-1}$. The interferometer is scanned at 80 scans $\mathrm{min}^{-1}$ and normally spectra are coadded for $1-10 \mathrm{~min}$ according to the required time resolution and signal-to-noise ratio. The root mean square (RMS) signal-to-noise ratio in the spectra for a 1-min average measurement $(\sim 80$ coadded spectra) through the cell at $1 \mathrm{~cm}^{-1}$ resolution is typically 40000-60000:1 (measured as 1/noise where noise is the RMS noise from $2500-2600 \mathrm{~cm}^{-1}$ on the ratio of two consecutively collected spectra). The signal-to-noise ratio (SNR) increases as the square root of averaging time for coadded spectra up to at least $20 \mathrm{~min}$.

The White cell is fitted with a $0-1333 \mathrm{hPa}$ piezo manometer to measure cell pressure and a type- $\mathrm{J}$ or type- $\mathrm{T}$ thermocouple in the cell for cell temperature measurement. Ambient water vapour, $\mathrm{CO}_{2}, \mathrm{CO}, \mathrm{CH}_{4}$ and $\mathrm{N}_{2} \mathrm{O}$ are removed from the internal volume of the IRcube and transfer optics with a slow purge of dry $\mathrm{N}_{2}\left(0.1-0.21 \mathrm{~min}^{-1}\right)$ backed by a molecular sieve and Ascarite ${ }^{\circledR}$ trap in the volume. The FTIR and sample cell are thermostatted, typically at $30^{\circ} \mathrm{C}$.

The evacuation and filling of the cell with sample or calibration gas is controlled by a manifold of solenoid valves, shown schematically in Fig. 2. A 4-stage oil-free diaphragm pump with ultimate vacuum of approximately $1 \mathrm{hPa}$ is used 
to evacuate and draw sample gas through the cell. Sample or calibration gas streams are introduced through one of four equivalent inlets (V1-V4). To minimise uncertainty due to cross-sensitivity to water vapour lines in the spectra (Sect. 3), the airstream can be optionally dried by passing through a Nafion ${ }^{\circledR}$ drier and $\mathrm{Mg}\left(\mathrm{ClO}_{4}\right)_{2}$ trap (selected by V9). The gas stream passes through a $7 \mu \mathrm{m}$ sintered stainless steel particle filter into the sample cell (V6). Flow is controlled by a mass flow controller at the cell outlet which can optionally function as a cell pressure controller through a feedback loop to the cell pressure transducer. In earlier versions of the analyser, a needle valve and mass flow meter were used instead of the mass flow controller. In the most recent versions, the addition of a second mass flow controller at the cell inlet (not shown) allows both pressure and flow to be controlled simultaneously. Flow rate is typically $0.5-1.51 \mathrm{~min}^{-1}$ and cell pressure is near ambient pressure. The dried sample gas stream leaving the cell provides the required backflush to the Nafion dryer at reduced pressure. The Nafion drier alone typically achieves water vapour mole fractions of $200-300 \mu \mathrm{mol} \mathrm{mol}^{-1}$ (dew point $<-40^{\circ} \mathrm{C}$ ) in the sampled airstream, and the $\mathrm{Mg}\left(\mathrm{ClO}_{4}\right)_{2}$ typically reduces this to $<10 \mu \mathrm{mol} \mathrm{mol}^{-1}$. Sample or calibration gas may also be analysed statically by evacuating and filling the cell without flow during the measurement. In this case a flow of dried air can be maintained through the Nafion drier via a cell-bypass valve (V5) to avoid step changes in water vapour levels that may occur if the Nafion drier is not continuously flushed. The cell can be evacuated directly through V8.

The solenoid manifold valves are switched by a digital output (DO) relay module connected to the controlling computer via a RS232-RS485 serial interface. An 8-channel, 16bit analogue-digital converter (ADC) module is connected via the same RS485 daisy-chain to log pressure, cell and room temperatures, flow and other desired analogue signals. The mass flow controller is controlled by an analogue output (AO) module. Additional DO, AO or ADC modules can be added as required to the RS485 daisy chain for special applications. Operation of the spectrometer, sample manifold, data logging, spectrum analysis (described below) and real time display of gas concentrations is controlled by a single program ("Oscar") written in Microsoft Visual Basic. The spectrometer communication is via Bruker's OPUS DDE interface over a private Ethernet network. The DO, AO and ADC modules are connected via the PC's serial RS232 port. Oscar provides for the configuration and fully automated execution of user-defined sequences of valve-switching for flow control, spectrum collection, spectrum quantitative analysis, logging and display. Different sequences may be executed in turn and looped to provide continuous automated operation, including periodic calibration tank measurements, without manual intervention. The instrument can be run remotely via an Ethernet connection to the PC.

\subsection{Quantitative spectrum analysis}

Spectra are analysed to determine the amounts of selected trace gases in the cell by non-linear least squares fitting of broad regions $\left(100-200 \mathrm{~cm}^{-1}\right)$ of the spectrum selected for each target gas. The analysis is carried out automatically after spectrum collection, and the results logged and displayed on the controlling computer. Spectroscopic analysis fundamentally determines the total absorber amount (concentration $\times$ pathlength, $C \times L$ ) of the target trace gas, from which the mole fraction $\chi$ of the trace gas in air is calculated from the molar concentration of air, $n / V=P / \mathrm{RT}$

$\chi=\frac{C}{P / \mathrm{RT}}$,

where $P$ is the measured sample pressure, $T$ the sample cell temperature, and $R$ the universal gas constant. From Eq. (1), $\chi$ is the mole fraction in whole air. $\chi$ can be converted to dry air mole fraction using the measured mole fraction of water vapour in the sampled air in the cell determined simultaneously from the FTIR spectrum, as in Eq. (2):

$\chi_{\text {dry }}=\frac{\chi}{\left(1-\chi_{\mathrm{H}_{2} \mathrm{O}}\right)}$.

For dried air, $\chi_{\mathrm{H}_{2} \mathrm{O}}$ is generally small $\left(<10 \mu \mathrm{mol} \mathrm{mol}^{-1}\right)$ and the correction to dry air mole fraction is negligible. The quantitative spectrum analysis takes a computational approach in which the spectral region to be analysed is iteratively calculated and fitted to the measured spectrum by non-linear least squares.. The spectrum model, MALT (Multiple Atmospheric Layer Transmission), is described in detail elsewhere (Griffith, 1996) and only summarised here. For most trace gases of interest, the positions, strengths, widths and temperature dependences of relevant absorption lines are available in the HITRAN database (Rothman et al., 2005). From the HITRAN line parameters, the MALT spectral model calculates the absorption coefficients of the gas sample in the cell at the measured temperature and pressure. For samples containing gases that are not included in HITRAN, the absorption coefficients can be calculated from quantitative library reference spectra if available; for example, the Northwest Infrared Vapour Phase Reference Library provides such data for over 400 compounds (https://secure2. pnl.gov/nsd/nsd.nsf/Welcome, see also (Sharpe et al., 2004; Johnson et al., 2010). The monochromatic (i.e. true, infinite resolution) transmittance spectrum is calculated from the absorption coefficients and initial estimates of trace gas concentrations, then convolved with the FTIR instrument lineshape (ILS) function, which includes the effects of resolution (maximum optical path difference of the interferogram), apodization, and finite field of view (beam divergence in the interferometer). In addition, effects of imperfect alignment or optics can be included, for example wavenumber scale shift, loss of modulation efficiency at high optical path difference, 
and residual phase error, which may lead to shifted, broadened and asymmetric lineshapes, respectively. The resulting calculated spectrum simulates the measured spectrum, and is iteratively re-calculated using a Levenberg-Marquardt algorithm (Press et al., 1992) to update estimates of absorber amounts and ILS parameters until the best fit (minimum sum of squared residuals between measured and calculated spectra) is achieved.

The transmittance model is not linear in the fitted parameters (absorber amounts and ILS), necessitating the iterative non-linear least squares fitting. This method is fundamentally different from methods commonly used in chemometric approaches to quantitative spectrum analysis, and in particular the classical least squares (CLS) or partial least squares (PLS) used in earlier work (Griffith, 1996). These chemometric approaches are applied to absorbance spectra and fit the spectrum as a linear combination of single component absorbance spectra (CLS) or factors (PLS). They inherently assume that Beer's Law (i.e. that absorbance is proportional to concentrations of absorbers) is obeyed or nearly obeyed, but cannot fit spectral variations due to ILS effects, and are restricted to regions of weak absorption to avoid non-linearities and breakdown of Beer's Law (Anderson and Griffiths, 1975; Haaland, 1987). In non-linear least squares the transmittance spectrum can be fitted in any region, not just one of weak absorption, because there is no assumption of linearity between transmittance and trace gas concentrations. All spectral points have the same measurement noise error independent of the transmittance, and therefore have equal weight in calculating and minimising the residual sum of squares.

The iterative fit normally takes 5-10 iterations and a few seconds of computation time on a typical personal computer. Figure 3 illustrates spectral fits to typical regions: (a) 2150 $2310 \mathrm{~cm}^{-1}$ for $\mathrm{CO}_{2}$ isotopologues, $\mathrm{CO}$ and $\mathrm{N}_{2} \mathrm{O}$, (b) 2097$2242 \mathrm{~cm}^{-1}$ optimised for $\mathrm{N}_{2} \mathrm{O}$ and $\mathrm{CO}$ (c) $3001-3150 \mathrm{~cm}^{-1}$ for $\mathrm{CH}_{4}$, and (d) $3520-3775 \mathrm{~cm}^{-1}$ for $\mathrm{CO}_{2}$ (all isotopologues) and $\mathrm{H}_{2} \mathrm{O}$. Water vapour is fitted in all spectral regions because there are weak residual water vapour lines even in dried air. In undried air, $\mathrm{H}_{2} \mathrm{O}, \mathrm{HDO}$ and $\mathrm{H}_{2}^{18} \mathrm{O}$ in the sample can be independently determined to provide the hydrogen and oxygen isotopic composition in water vapour (Parkes et al., 2012). In the region near $2300 \mathrm{~cm}^{-1}$ the ${ }^{13} \mathrm{C}$ and ${ }^{12} \mathrm{C}$ isotopologues of $\mathrm{CO}_{2}$ are well resolved (the ${ }^{13} \mathrm{CO}_{2}$ asymmetric stretching band is shifted $66 \mathrm{~cm}^{-1}$ from the corresponding ${ }^{12} \mathrm{CO}_{2}$ band) and can be fitted independently, allowing a direct measurement of ${ }^{13} \mathrm{C}$ in atmospheric $\mathrm{CO}_{2}$. In general, overlap of absorption bands of different gases is accounted for by the MALT spectral model and isolated spectral features are not required for analysis. However, crosssensitivities may be significant with overlap of a weak band by a much stronger band, such as is the case for $\mathrm{N}_{2} \mathrm{O}$ and ${ }^{13} \mathrm{CO}_{2}$ shown in Fig. 3a; in this case an additional window from $2097-2242 \mathrm{~cm}^{-1}$ shown in Fig. $3 \mathrm{~b}$ can be used to minimise this cross-sensitivity.
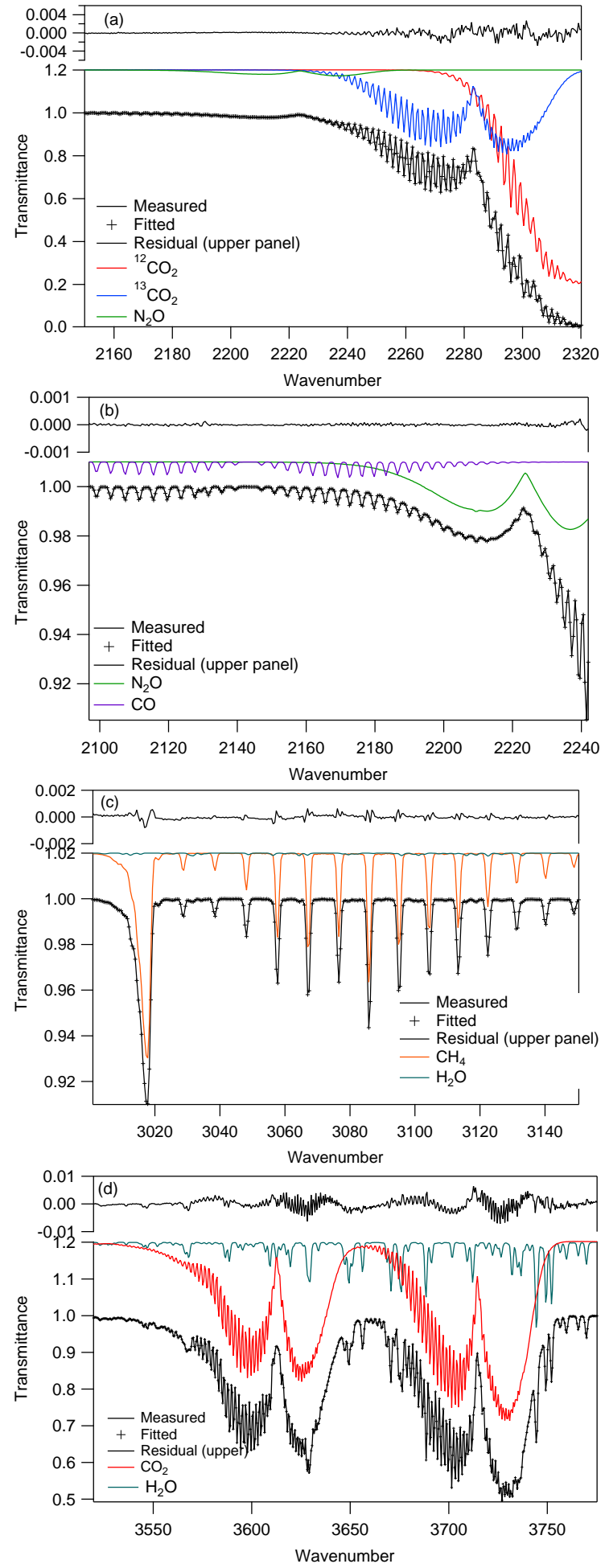

Fig. 3. Typical non-linear least squares fits to a spectrum of dry air in four spectral regions. (a) $2150-2310 \mathrm{~cm}^{-1}$, fitting $\mathrm{CO}_{2}$ isotopologues, $\mathrm{CO}, \mathrm{N}_{2} \mathrm{O}$ and $\mathrm{H}_{2} \mathrm{O}$; (b) 2097-2242 $\mathrm{cm}^{-1}$, optimised for $\mathrm{N}_{2} \mathrm{O}$ and $\mathrm{CO}$, also fitting $\mathrm{CO}_{2}$; (c) $3001-3150 \mathrm{~cm}^{-1}$, fitting $\mathrm{CH}_{4}$ and $\mathrm{H}_{2} \mathrm{O}$; (d) $3520-3775 \mathrm{~cm}^{-1}$, fitting $\mathrm{CO}_{2}$ and $\mathrm{H}_{2} \mathrm{O}$. Contributions from individual species are shown in colours, offset +0.2 units for clarity. 

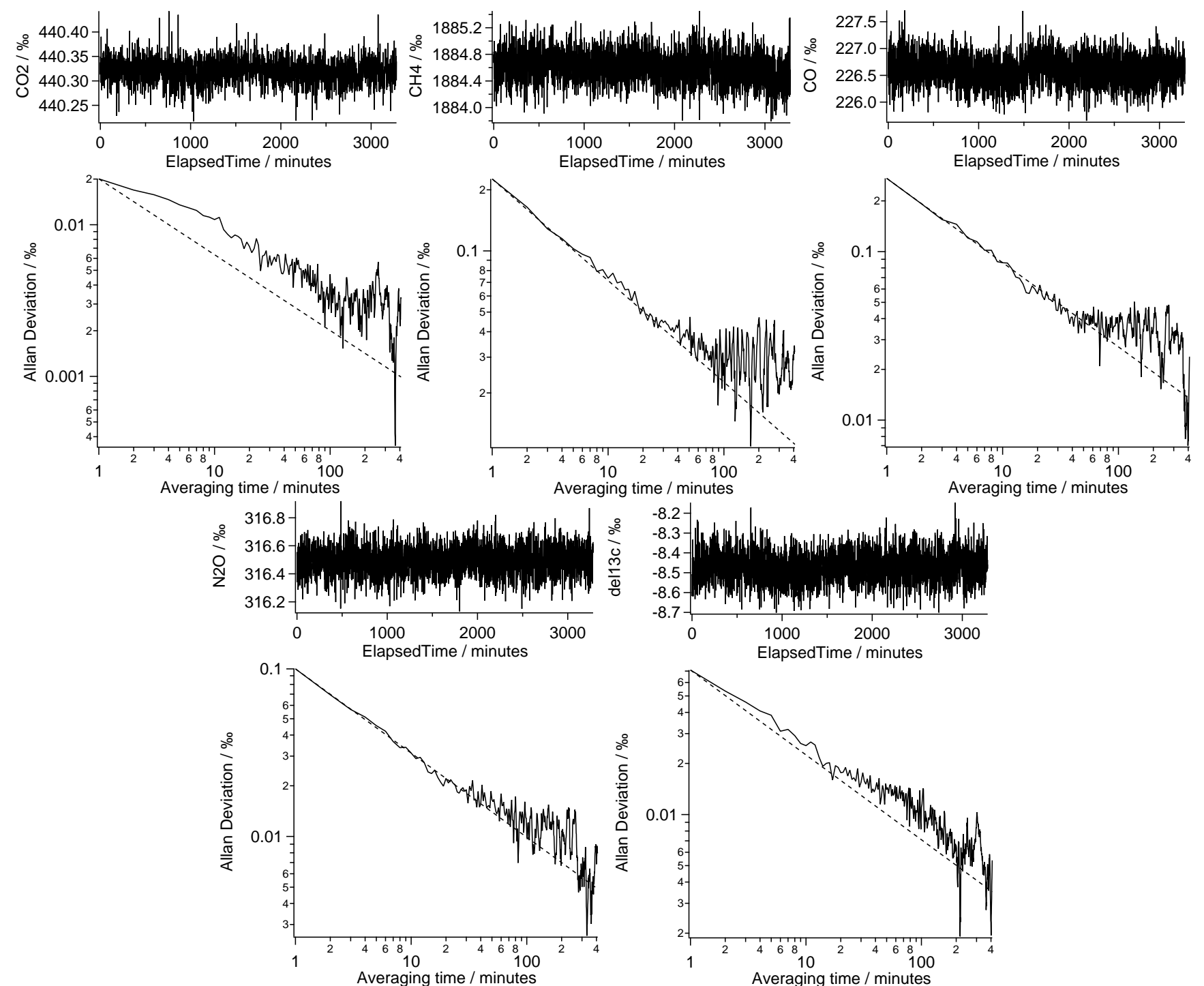

Fig. 4. Time series (upper panels) and Allan deviation (lower panels) plots of consecutive 1-min average measurements of $\mathrm{CO}_{2}, \mathrm{CH}_{4}, \mathrm{CO}_{\text {, }}$ $\mathrm{N}_{2} \mathrm{O}$ and $\delta^{13} \mathrm{C}$ in $\mathrm{CO}_{2}$ for an unchanging air sample in the FTIR analyser. The dashed lines have a slope of -0.5 (log-log) and show the expected behaviour of the Allan deviation vs. time for random (white) noise.

All spectra are stored after measurement and archived. An advantage of the method is that spectra can be re-analysed at any later time, for example with a different choice of spectral regions or with improved line parameters when/if they become available.

The fitting procedure provides trace gas amounts and ILS parameters without any reference to calibration spectra of reference gases. For an ideal measured spectrum from a perfectly aligned spectrometer, the fitted spectrum residual should show only random detector noise, and absolute accuracy would depend only on the HITRAN line parameters, pressure, temperature and pathlength measurements. In reality, the raw FTIR determination of trace gas concentrations is highly precise, but typically uncertain to within a few per- cent of calibrated reference scales due to systematic errors in the spectrometer, MALT model, HITRAN data and measured pressure and temperature (Smith et al., 2011). Higher accuracy, equivalent to the precision of repeated measurements, is achieved by analysis of calibration standards that have known concentrations traceable to accepted standard scales such as the WMO scales for clean air (GAW, 2011). Calibration equations can be derived by analysis of such standards. Characterisation of the precision and accuracy is described in the following section.

The analyser and spectral analysis procedure has been developed and improved over several years since the first versions described by Esler et al. (2000a, b). Since 2011, the analyser described above, with refinements, has been 
available commercially as the Spectronus analyser from Ecotech Pty Ltd., Knoxfield, Australia.

\section{Precision, accuracy and calibration}

\subsection{Precision}

Precision may be quantified as repeatability (the closeness of the agreement between the results of successive measurements of the same measurand carried out under the same conditions of measurement) or reproducibility (where the conditions of measurement may include different operators, locations and techniques). Accuracy is defined as the closeness of the agreement between the result of a measurement and a true value of the measurand (JCGM, 2008, see also http://gaw.empa.ch/glossary.html).

Repeatability of the FTIR analyser is determined as the standard deviation of replicate measurements of a gas sample of constant composition, for example a set of measurements of a constant air sample in the sample cell. Figure 4 illustrates the analyser's repeatability with time series (upper panels) and Allan deviation (lower panels) of consecutive 1min measurements of $\mathrm{CO}_{2}, \mathrm{CH}_{4}, \mathrm{CO}, \mathrm{N}_{2} \mathrm{O}$ and $\delta^{13} \mathrm{C}$ in $\mathrm{CO}_{2}$ in dry air. For these measurements the cell was slowly flushed with dried air from a high pressure tank, and spectra collected continuously for more than 2 days $(54 \mathrm{~h})$. Pressure in the cell was controlled at $1100 \mathrm{hPa}$.

Allan variance is commonly used to characterise noise in repeated measurements (Allan, 1966; Werle et al., 1993) and expresses the measurement variance as a function of averaging time. In Fig. 4 the plotted Allan deviation is the square root of the Allan variance. If the variance is dominated by white (Gaussian) noise, as should occur in the ideal case when the precision is detector noise limited, the Allan variance should decrease linearly with averaging time, and the log plots of Allan deviation in Fig. 4 should have slope of -0.5 , as indicated by the dotted lines. From Fig. 4 it can be seen that in most cases the Allan deviation decreases with $\sqrt{\text { time }}$ for at least $30 \mathrm{~min}$. Repeatabilities (as Allan deviations) for averaging times of 1 and $10 \mathrm{~min}$ are summarised in Table 1 . These repeatabilities meet GAW compatibility requirements for baseline air monitoring (also listed in Table 1) for all species except $\delta^{13} \mathrm{C}$ in $\mathrm{CO}_{2}$.

\subsection{Calibration and accuracy}

The least squares fitting of spectra provides trace gas concentrations for which the accuracy depends on the FTIR instrument response, HITRAN line parameters, the MALT spectrum model and the accuracy of the least squares fitting procedure. The raw "FTIR" mole fraction scale also includes measurements of sample pressure and temperature (Eq. 1) and their associated uncertainties. The raw FTIR measurements are precise as described above, but absolute uncertainty may be up to a few percent (Smith et al., 2011). Cal-

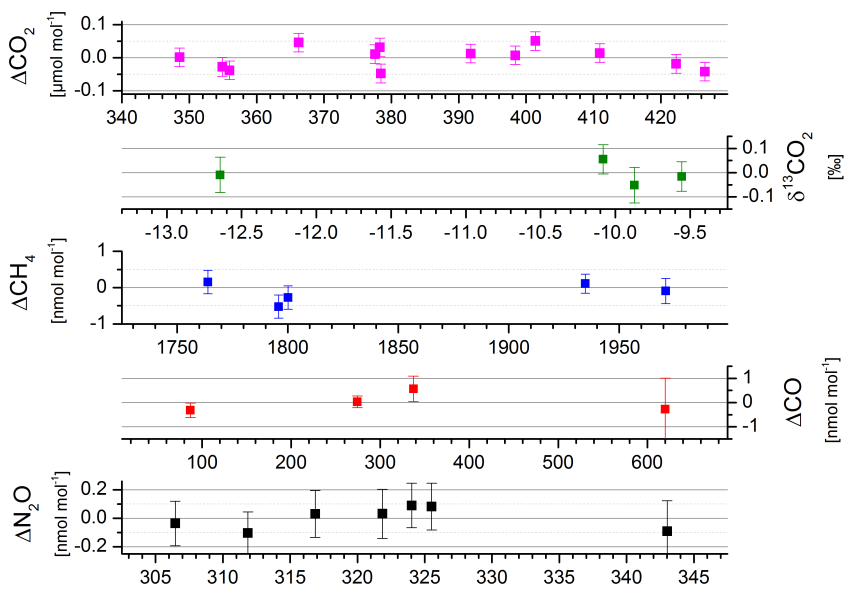

Fig. 5. Residuals with $1 \sigma$ error bars from linear regressions of raw FTIR measured mole fractions against reference mole fractions for a suite of tanks maintained by the University of Heidelberg (data and further details from Hammer et al., 2012).

ibration of the analyser to an absolute or reference scale is achieved by measurements of two or more tanks of air independently calibrated for each trace gas on the reference scales. Calibration is described in detail in an accompanying paper by Hammer et al. (2012); combined uncertainty is shown to exceed GAW compatibility targets (Table 1) for all species except $\delta^{13} \mathrm{C}$ in $\mathrm{CO}_{2}$. Griffith et al. (2011) and Hammer et al. (2012) demonstrate that the raw FTIR scale is linear relative to WMO reference scales over a range of mole fractions typical of ambient air and above. While the calibration regressions are in general linear within the measurement error limits, they have small but significant non-zero $y$-axis intercepts, so the general calibration equation for each species is expressed as

$\chi_{\text {meas }}=a \chi_{\text {ref }}+b$,

where $a$ and $b$ are the coefficients derived from slope and intercept of the regression.

Figure 5 shows residuals from linear regressions of FTIRmeasured mole fractions against reference values from a suite of standard tanks maintained at the University of Heidelberg (data from Hammer et al., 2012). Similar measurements over wider mole fraction ranges for a suite of tanks at CSIRO's GASLAB also show no significant deviations from linearity (albeit with lower precision) (Griffith et al., 2011). Possible effects of small non-linearities are observed in the calibration of $\delta^{13} \mathrm{C}$ in $\mathrm{CO}_{2}$ measurements, described below.

\subsection{Calibration stability}

The Allan variance plots of Fig. 4 (upper panels) illustrate the uncalibrated variability of the FTIR response for continuous 1-min average measurements of a single tank gas over a two day period; in general the drift remained within the 
Table 2. Linear sensitivities $\mathrm{d} \chi / \mathrm{d}$ (quantity) of trace gas measurements to quantities pressure, temperature, flow and other trace gases in the sample. From Hammer et al. (2012).

\begin{tabular}{|c|c|c|c|c|c|}
\hline$\frac{\mathrm{d} \chi}{\mathrm{d}}$ (quantity) & $\begin{array}{r}\mathrm{CO}_{2} \mu \\
\mathrm{mol} \mathrm{mol}^{-1}\end{array}$ & $\begin{array}{r}\delta^{13} \mathrm{C}- \\
\mathrm{CO}_{2} \% \text { - }\end{array}$ & $\begin{array}{r}\mathrm{CH}_{4} \mu \\
\mathrm{mol} \mathrm{mol}^{-1}\end{array}$ & $\begin{array}{r}\mathrm{CO} \mu \\
\mathrm{mol} \mathrm{mol}^{-1}\end{array}$ & $\begin{array}{r}\mathrm{N}_{2} \mathrm{O} \mu \\
\mathrm{mol} \mathrm{mol}^{-1}\end{array}$ \\
\hline Pressure hPa & 0.0085 & 0.005 & 0.031 & 0.006 & 0.007 \\
\hline Equil. Temp. ${ }^{\circ} \mathrm{C}$ & $<0.8$ & 0.6 & $<1.6$ & $<1$ & 0.6 \\
\hline Disequil. Temp. ${ }^{\circ} \mathrm{C}$ & 2.07 & 4.1 & -4.6 & 10.2 & 3.2 \\
\hline Flow 1 in $^{-1}$ & 0.15 & -0.9 & $<4$ & $<2$ & $<-0.8$ \\
\hline Residual $\mathrm{H}_{2} \mathrm{O} \mu \mathrm{mol} \mathrm{mol}{ }^{-1}$ & 0.04 & - & $<0.2$ & $<0.2$ & - \\
\hline $\mathrm{CO}_{2} \mu \mathrm{mol} \mathrm{mol}-1$ & - & $0.006^{*}$ & - & 0.006 & 0.008 \\
\hline
\end{tabular}

$* \mathrm{CO}_{2}$ sensitivity is more accurately treated as proportional to inverse mole fraction as described above.

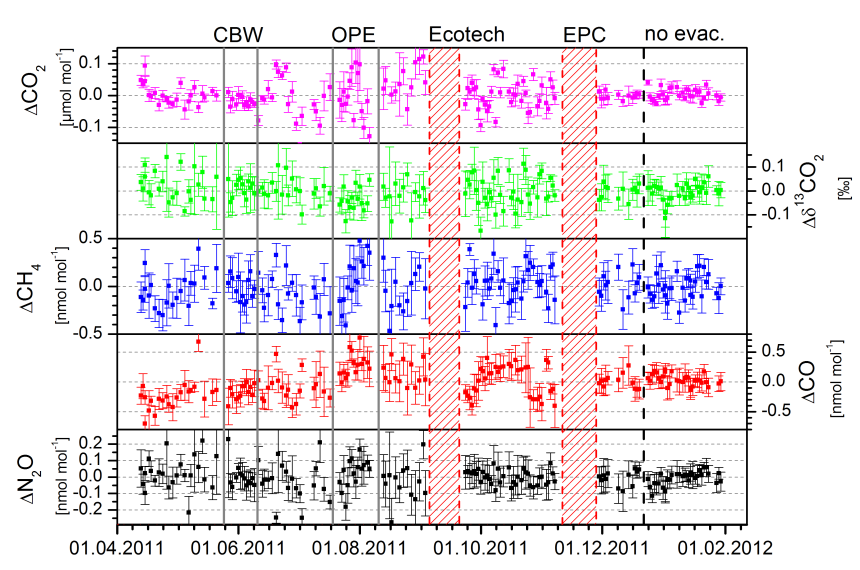

Fig. 6. Measurement residuals with $1 \sigma$ error bars relative to a reference value for a single target tank over a 10 month period (from Hammer et al., 2012). During this period, the FTIR analyser was based in Heidelberg except for two field campaigns at Cabauw, Netherlands (CBW) and Houdelaincourt, France (OPE). "Ecotech" refers to a rebuild of the instrument to include the mass flow controller (Sect. 2), and "EPC" refers to the addition of an electronic pressure controller upstream of the analyser in the sample airstream. "No evac" refers to a period where ambient and target gas in the cell was exchanged by switching flow alone, without evacuation of the cell.

repeatability summarised in Table 1 over the whole period. Hammer et al. (2012) show similar stability over six days but some species show small significant drifts at the precision limit. Figure 6, also from Hammer et al. (2012, Fig. 9), illustrates longer-term calibration stability with residuals of approximately daily measurements of a target tank relative to its nominal mole fractions over a 10 -month period. The analyser was calibrated against 2 standards typically every day or two days. The calibration stability for all species except $\delta^{13} \mathrm{C}$ in $\mathrm{CO}_{2}$ meets GAW compatibility levels (Table 1). Hammer et al. (2012) conclude that for most applications weekly calibrations would be sufficient to ensure total uncertainty meeting WMO-GAW targets in continuous measurements.

\subsection{Cross sensitivities}

Raw measured mole fractions of trace gases from the FTIR analyser may show small but significant residual sensitivities to pressure, temperature, flow and water vapour in the sample that are not removed by the spectrum analysis and calibration procedures. These cross-sensitivities may be due to imperfections in the measured spectra, and systematic errors in the HITRAN database, MALT analysis procedure, temperature and pressure measurements. Hammer et al. (2012) have investigated and quantified these sensitivities in detail for one analyser, and provide a set of linear correction coefficients for sensitivity to cell pressure, cell temperature, cell flow and residual water vapour amount in the spectrum. These sensitivities are typical of all analysers we have built and tested to date, and are summarised in Table 2. The uncertainty in determining water vapour cross-sensitivities is such that drying the airstream to reduce the cross-sensitivity correction is recommended for the most accurate measurements. In almost all cases, the sensitivities for reasonable variations in the quantities are small and can be corrected to within GAW compatibility targets. These corrections are applied to raw measured mole fractions before calibration to reference mole fraction scales.

Hammer et al. (2012) also found cross-sensitivity of CO and $\mathrm{N}_{2} \mathrm{O}$ measurements to $\mathrm{CO}_{2}$ mole fraction in the sample when analysing spectra in the region shown in Fig. 3a. This sensitivity can be significant in situations where the $\mathrm{CO}_{2}$ mole fraction may vary significantly between samples (for example chamber or nocturnal boundary layer measurements). However, this sensitivity can be reduced to insignificance by the use of the $2097-2242 \mathrm{~cm}^{-1}$ region (Fig. 3b), which avoids most spectral interference of the absorptions of $\mathrm{N}_{2} \mathrm{O}$ and $\mathrm{CO}$ with $\mathrm{CO}_{2}$.

\subsection{Calibration for $\delta^{13} \mathrm{C}$ in $\mathrm{CO}_{2}$}

Chen et al. (2010), Griffith et al. (2011) and Loh et al. (2011) have considered isotopologue-specific trace gas calibration in optical analysers. Spectroscopic analysers such as the FTIR and laser analysers determine the mole fractions of 
Table 3. HITRAN isotopologue natural abundances.

\begin{tabular}{lrr}
\hline Isotopologue & Notation & Abundance $\mathrm{X}_{\text {iso }}$ \\
\hline${ }^{16} \mathrm{O}^{12} \mathrm{C}^{16} \mathrm{O}$ & 626 & 0.98420 \\
${ }^{16} \mathrm{O}^{13} \mathrm{C}^{16} \mathrm{O}$ & 636 & 0.01106 \\
${ }^{16} \mathrm{O}^{12} \mathrm{C}^{18} \mathrm{O}$ & 628 & 0.0039471 \\
${ }^{16} \mathrm{O}^{12} \mathrm{C}^{17} \mathrm{O}$ & 627 & 0.000734 \\
\hline
\end{tabular}

isotopologues as individual species, from which the conventional $\delta$ values are directly calculated. In the following, we use International Union of Pure and Applied Chemistry (IUPAC) recommendations (Cohen et al., 2007; Coplen, 2008) to distinguish the following quantities:

$$
\begin{aligned}
& C \text { concentration, e.g. } \mathrm{mol} \mathrm{m}^{-3} \\
& \chi \text { mole fraction of trace gas, e.g. } \mu \mathrm{mol} \mathrm{mol}^{-1}, \mathrm{ppm}
\end{aligned}
$$

$X$ isotopic abundance of an isotope or isotopologue, mol $\mathrm{mol}^{-1}$

\section{$R$ isotope ratio}

Linestrengths in the HITRAN database (Rothman et al., 2005, 2009) are scaled by the natural abundance for each isotopologue, so that the actual measured isotopologue mole fraction $\chi_{\text {iso }}$ for an individual isotopologue is reported as the scaled mole fraction $\chi^{\prime}$ iso:

$\chi_{\text {iso }}^{\prime}=\frac{\chi_{\text {iso }}}{X_{\text {iso }}}$

where $X_{\text {iso }}$ is the natural isotopologue abundance assumed in HITRAN, as shown in Table 3 for the major $\mathrm{CO}_{2}$ isotopologues (Rothman et al., 2005). With this definition, FTIR analysis of a sample of $\mathrm{CO}_{2}$ with all isotopes in natural abundance, as specified in HITRAN, and perfect calibration would report the same raw numerical value of $\chi^{\prime}$ iso for each isotopologue.

$\delta^{13} \mathrm{C}$ in $\mathrm{CO}_{2}$ is calculated from the individual mole fractions $\chi_{636}$ and $\chi_{626}$ and natural abundances $X_{636}$ and $X_{626}$ :

$\delta^{13} \mathrm{C}=\frac{\chi_{636}^{\prime}}{\chi_{626}^{\prime}}-1=\frac{\chi_{636} / \chi_{626}}{X_{636} / X_{626}}-1$,

where $\chi_{636} / \chi_{626}$ is equivalent to the usual sample isotope ratio $R_{\text {sample }}^{13}$ and $X_{636} / X_{626}$ is equivalent to the standard isotope ratio $R_{\text {std }}^{13}$. $\delta^{13} \mathrm{C}$ is normally multiplied by 1000 and expressed in $\%$, but for clarity the factor $1000 \%$ is not explicitly written in the following. The reference scale for $\delta^{13} \mathrm{C}$ in Eq. (5) is thus that of HITRAN. Calibration of isotopologuespecific measurements against reference standards calibrated to the standard Vienna Pee Dee Belomnite (VPDB) corrects simultaneously for both the difference between HITRAN and
VPDB scales and calibration factors in the isotopologuespecific FTIR measurements of $\chi_{636}$ and $\chi_{626}$, as detailed below.

In applying the calibration Eq. (3) to individual isotopologues, we must know the individual isotopologue mole fractions in the reference standards. For parent and ${ }^{13} \mathrm{C}$ isotopologues of $\mathrm{CO}_{2}$, these can be calculated from the (assumed known) total $\mathrm{CO}_{2}$ mole fractions and isotopic $\delta$ values for the standard as follows:

The total $\mathrm{CO}_{2}$ mole fraction is

$$
\begin{aligned}
\chi_{\mathrm{CO}_{2}} & =\chi_{626}+\chi_{636}+\chi_{628}+\chi_{627}+\ldots \\
& =\chi_{626}^{\prime} X_{626}+\chi_{636}^{\prime} X_{636}+\chi_{628}^{\prime} X_{628}+\ldots
\end{aligned}
$$

From the definition of $\delta$, Eq. (5),

$$
\begin{aligned}
& \chi_{636}^{\prime}=\left(1+\delta^{13} \mathrm{C}\right) \chi_{626}^{\prime} \\
& \chi_{628}^{\prime}=\left(1+\delta^{18} \mathrm{O}\right) \chi_{626}^{\prime} \\
& \chi_{627}^{\prime}=\left(1+\delta^{17} \mathrm{O}\right) \chi_{626}^{\prime}
\end{aligned}
$$

and Eq. (6) can be written

$\chi_{\mathrm{CO}_{2}}=\chi_{626}^{\prime} \cdot\left(X_{626}+\sum_{i}\left(1+\delta^{i}\right) X_{i}\right)=\chi_{626}^{\prime} \cdot X$,

where $X=X_{626}+\sum_{i}\left(1+\delta^{i}\right) X_{i}$ and the index $i$ runs over all isotopologues except 626. Thus,

$\chi_{626}^{\prime}=\frac{\chi_{\mathrm{CO}_{2}}}{X}$

and from Eq. (7) the mole fraction of ${ }^{13} \mathrm{CO}_{2}$ is

$\chi_{636}^{\prime}=\frac{\left(1+\delta^{13} \mathrm{C}\right) \cdot \chi_{\mathrm{CO}_{2}}}{X}$

and similarly for the other isotopologues. To compute $X$, all values of $\delta^{i}$ and $X_{i}$ must therefore be known. To calculate individual isotopologue mole fractions via Eq. (10), the total $\mathrm{CO}_{2}$ mole fraction must also be known. For calibration standards $\delta^{13} \mathrm{C}$ and $\delta^{18} \mathrm{O}$ are usually known, and with sufficient accuracy for FTIR calibrations we can assume $\delta^{17} \mathrm{O}=0.5 \cdot \delta^{18} \mathrm{O}$ and all $\delta=0$ for multiply-substituted isotopologues since their contributions to the sum are very small.

To generate an isotopologue-specific calibration following Eq. (3), the reference mole fractions $\chi_{\text {ref }}$ should be calculated from Eqs. (9) and (10) for the regressions of $\chi_{\text {meas }}$ vs. $\chi_{\text {ref }}$. If calibrated measurements of $\chi^{\prime} 626$ and $\chi^{\prime} 636$ are used to calculate $\delta^{13} \mathrm{C}$ following Eq. (5), the result should require no further calibration.

However, if uncalibrated $\chi^{\prime}{ }_{626}$ and $\chi^{\prime}{ }_{636}$ are used to calculate $\delta^{13} \mathrm{C}$ directly, the result is not simply a linear relation to the reference $\delta^{13}$, because in general it also depends on the mole fraction of $\mathrm{CO}_{2}$ in the sample as follows from Eq. (5):

$$
\begin{aligned}
\delta^{13} \mathrm{C}_{\text {meas }} & =\frac{\chi^{\prime} 636, \text { meas }}{\chi^{\prime} 626, \text { meas }}-1 \\
& =\frac{a_{636} \cdot \chi^{\prime} 636+b_{636}}{a_{626} \cdot \chi^{\prime} 626+b_{626}}-1,
\end{aligned}
$$


which can be rearranged to

$$
\begin{gathered}
\delta^{13} \mathrm{C}_{\text {meas }}=\frac{a_{636} \chi^{\prime}{ }_{626}}{a_{626} \chi_{626}^{\prime}+b_{626}} \delta^{13} \mathrm{C}_{\text {ref }} \\
+\frac{\left(a_{636}-a_{626}\right) \chi_{626}^{\prime}+b_{636}-b_{626}}{a_{626} \chi_{626}^{\prime}+b_{626}} .
\end{gathered}
$$

If the intercepts $b$ are zero, Eq. (12) reduces to a simple scale shift $\alpha$

$\delta^{13} \mathrm{C}_{\text {meas }}=\alpha \cdot \delta{ }^{13} \mathrm{C}_{\text {ref }}+(\alpha-1)$,

where $\alpha=\frac{a_{636}}{a_{626}}$ and the measured and reference $\delta$ scales are related by the ratio of isotopologue calibration scale factors $a_{636}$ and $a_{626}$ only. However, if $b_{636}$ and $b_{626}$ are non-zero, the slope and intercept of Eq. (12) become $\mathrm{CO}_{2}$ mole fraction dependent and the regression over a range of $\mathrm{CO}_{2}$ mole fractions is not linear.

To summarise, there are thus two methods to approach $\delta^{13} \mathrm{C}$ calibration, as specified below.

\section{Method 1: Absolute calibration}

If a suite of reference gases of known $\mathrm{CO}_{2}$ mole fraction and isotopic composition is available to generate individual isotopologue calibrations, $\delta^{13} \mathrm{C}$ can be calculated from Eq. (5) directly using the true, calibrated values of $\chi^{\prime}{ }_{626}$ and $\chi^{\prime} 636$ obtained following Eqs. (9), (10) and (3). This requires calibration of both $\chi_{626}^{\prime}$ and $\chi_{636}^{\prime}$ to the same level of uncertainty as required for $\delta^{13} \mathrm{C}$, typically $<0.1 \%$.

\section{Method 2: empirical calibration}

If a suite of reference gases is not available, calibration for $\delta^{13} \mathrm{C}$ can still be established from one or more calibration gases of known $\mathrm{CO}_{2}$ mole fraction and isotopic composition, provided the $\mathrm{CO}_{2}$ mole fraction dependence in Eq. (12) is taken into account. Equation (12) can be rearranged in terms of the measured $\mathrm{CO}_{2}$ mole fraction $\chi^{\prime} 626$ as

$$
\begin{aligned}
\delta^{13} \mathrm{C}_{\text {meas }} & =\alpha \cdot \delta^{13} C_{\text {ref }}+(\alpha-1)+\frac{b_{636}-\alpha \cdot\left(1+\delta^{13} C_{\text {ref }}\right) \cdot b_{626}}{\chi_{626, \text { meas }}^{\prime}} \\
& =\alpha \cdot \delta^{13} C_{\text {ref }}+(\alpha-1)+\frac{\beta}{\chi_{626, \text { meas }}^{\prime}},
\end{aligned}
$$

where $\beta=b_{636}-\alpha \cdot\left(1+\delta^{13} C_{\text {ref }}\right) \cdot b_{626}$. Equation (14) reduces to Eq. (13) if the $b$ values are zero.

In Eq. (14) $\alpha$ describes a scale shift determined by the ratio of isotopologue-specific calibration scale factors $\alpha=$ $a_{636} / a_{626}$, while $\beta$ quantifies an inverse $\mathrm{CO}_{2}$ dependence, determined principally by the difference between $b_{636}$ and $b_{626}$ (since $\alpha \sim 1$ and $\delta \sim 0$ ). If $\delta^{13} \mathrm{C}_{\text {meas }}$ is first corrected by subtracting the $\mathrm{CO}_{2}$ dependence (determined empirically as described below), the scale shift $\alpha$ can be determined from FTIR measurements of one or more reference tanks of known $\delta^{13} \mathrm{C}_{\text {ref. }}$.

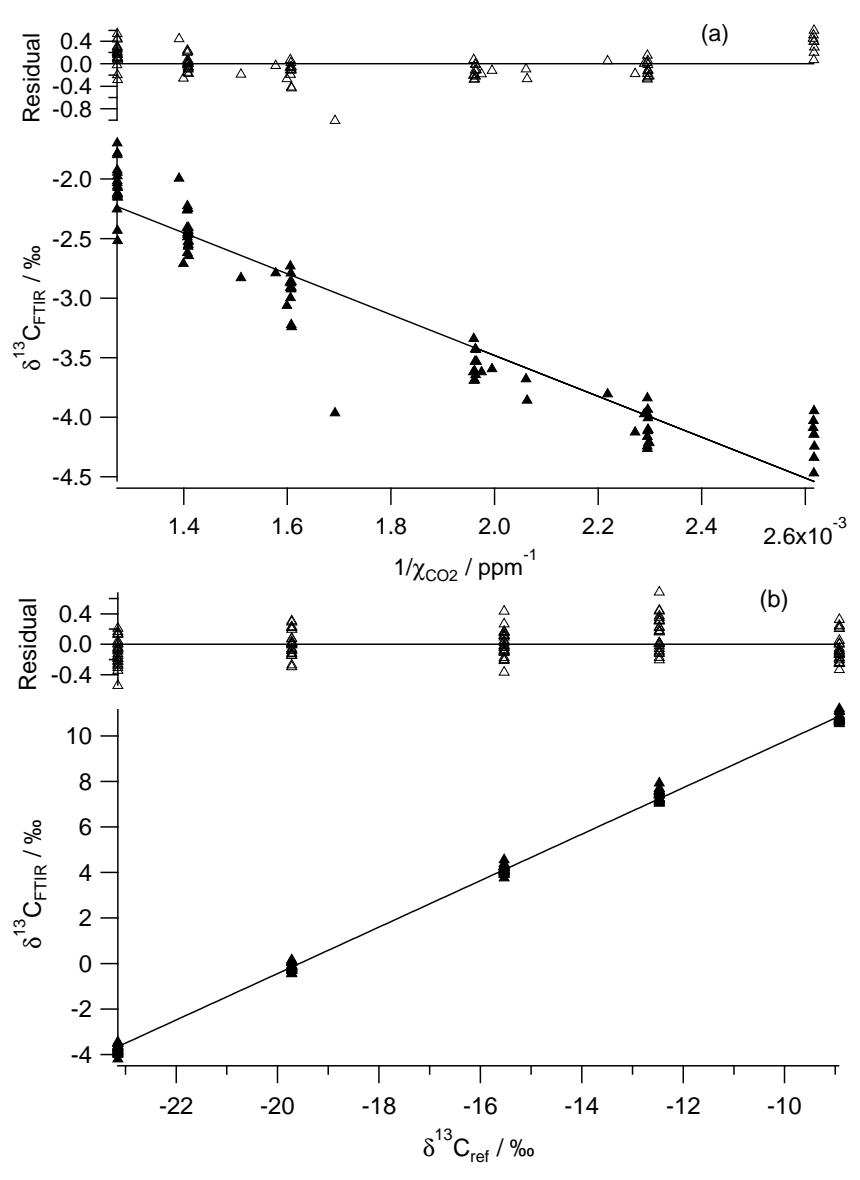

Fig. 7. (a) Empirical dependence of raw measured $\delta^{13} \mathrm{C}$ in $\mathrm{CO}_{2}$ on the inverse $\mathrm{CO}_{2}$ mole fraction, $1 / \chi_{\mathrm{CO}_{2}}$, following Eq. (14). Each point is from a $1 \mathrm{~min}$ average spectrum measured during the stepwise stripping sequence from 800 to $330 \mu \mathrm{mol} \mathrm{mol}{ }^{-1} \mathrm{CO}_{2}$. (b) Fit of Eq. (13) to $\delta^{13} \mathrm{C}$ measured by FTIR and corrected for $\mathrm{CO}_{2}$ dependence (see text) against reference values for five reference tanks with $\mathrm{CO}_{2}$ mole fractions $350-800 \mu \mathrm{mol} \mathrm{mol}^{-1}$ and $\delta^{13} \mathrm{C}$ values -8 to $-23 \%$. Each point is from a 1-min average spectrum after filling the measurement cell with reference gas. From the fit $\alpha=1.0199$, equivalent to a scale shift of $19.9 \%$.

The $\mathrm{CO}_{2}$ dependence of $\delta^{13} C_{\text {meas }}$ can be determined empirically by varying $\mathrm{CO}_{2}$ mole fraction at constant $\delta^{13} \mathrm{C}_{\text {ref }}$. Figure 7a illustrates such a measurement, where $\mathrm{CO}_{2}$ is gradually stripped stepwise from a flow of sample air from a tank. The flow is split into two streams in variable portions, one of which is scrubbed completely of $\mathrm{CO}_{2}$ with Ascarite or soda lime, and the two streams are recombined. Samples taken from the recombined flow and analysed independently by Isotope Ratio Mass Spectrometry (IRMS) confirm that there is no fractionation in the stripping process. The observed dependence on $\mathrm{CO}_{2}$ mole fraction is approximately proportional to $1 / \chi_{\mathrm{CO}_{2}}$, as expected from Eq. (14) with a fitted value of $\beta=-1715 \%$ opm. However, there is residual curvature in the plot against $1 / \chi_{\mathrm{CO} 2}$, which can be accounted for by including a linear term $\gamma \cdot \chi_{\mathrm{CO}_{2}}$ in the empirical fit. 
One possible source of this linear term is a very small nonlinearity of the analyser response; Eq. (14) assumes that the calibration equation, Eq. (3), is linear, but a small nonlinearity, represented by a quadratic term $c \chi_{\text {ref }}^{2}$ in Eq. (3), would lead to an additional linear term $\gamma \cdot \chi^{\prime} 626$ in Eq. (14) with the coefficient $\gamma$ determined approximately by the difference between $c_{636}$ and $c_{626}$. The value of $c_{636}-c_{626}$ required to account for the residual curvature in Fig. 7a, approximately $0.005 \% \mathrm{ppm}^{-1}$, is small enough to be consistent with the observed residuals in the individual 636 and 626 linear calibration regressions. The calibrations of Griffith et al. (2011) and Hammer et al. (2012) which showed the analyser to be "linear" would not have resolved a small non-linearity of this magnitude.

With $\delta^{13} \mathrm{C}_{\text {meas }}$ measured by FTIR corrected for the empirical $\mathrm{CO}_{2}$ dependence as above, $\alpha$ can be determined from Eq. (13) from measurements of one or more reference gases of known $\delta^{13} \mathrm{C}_{\text {ref. }}$. Fig. 7b shows such a case as a regression for five reference tanks, with $\mathrm{CO}_{2}$ mole fractions 350$800 \mu \mathrm{mol} \mathrm{mol}{ }^{-1}$ and $\delta^{13} \mathrm{C}$ values spanning -8 to $-23 \%$. The tanks were provided by MPI for Biogeochemistry, Jena. The best fit $\alpha=1.0199$, equivalent to a scale shift of $19.9 \%$.

\section{Results and selected applications}

The FTIR analyser has been used in a variety of applications for atmospheric measurements. An earlier version of the analyser is described by Esler et al. (2000a, b) and some earlier applications are reviewed by Griffith et al. (2002) and Griffith and Jamie (2000). Here we review recent applications as examples in clean air monitoring, tower profile measurements and chamber flux measurements which exploit the high precision and stability of the FTIR analyser.

\subsection{Clean air monitoring}

A core application of the FTIR analyser is in continuous monitoring of air at background and clean air sites. From November 2008-February 2009 we operated an analyser at the Cape Grim Baseline Air Pollution Station on the NW tip of Tasmania, Australia. At Cape Grim, unpolluted Southern Hemisphere marine air is sampled when the airflow is from the SW sector; Cape Grim is a key station of the GAW and AGAGE networks. The detailed results of the 3-month comparison between the FTIR analyser, LoFlo NDIR $\mathrm{CO}_{2}$ measurements and AGAGE GC measurements for $\mathrm{CH}_{4}, \mathrm{CO}$ and $\mathrm{N}_{2} \mathrm{O}$ have been reported previously (Griffith et al., 2011). Comparisons with LoFlo and AGAGE GC measurements for the 3-month period are shown in Fig. 8. For these data the CO calibration offset evident in Griffith et al. (2011) has been corrected for non-linearity in the AGAGE GC mercuric oxide reduction detector and the $\mathrm{CO}$ data are now in good agreement. While the LoFlo analyser clearly shows higher precision (less scatter) than the FTIR, for the AGAGE GC system

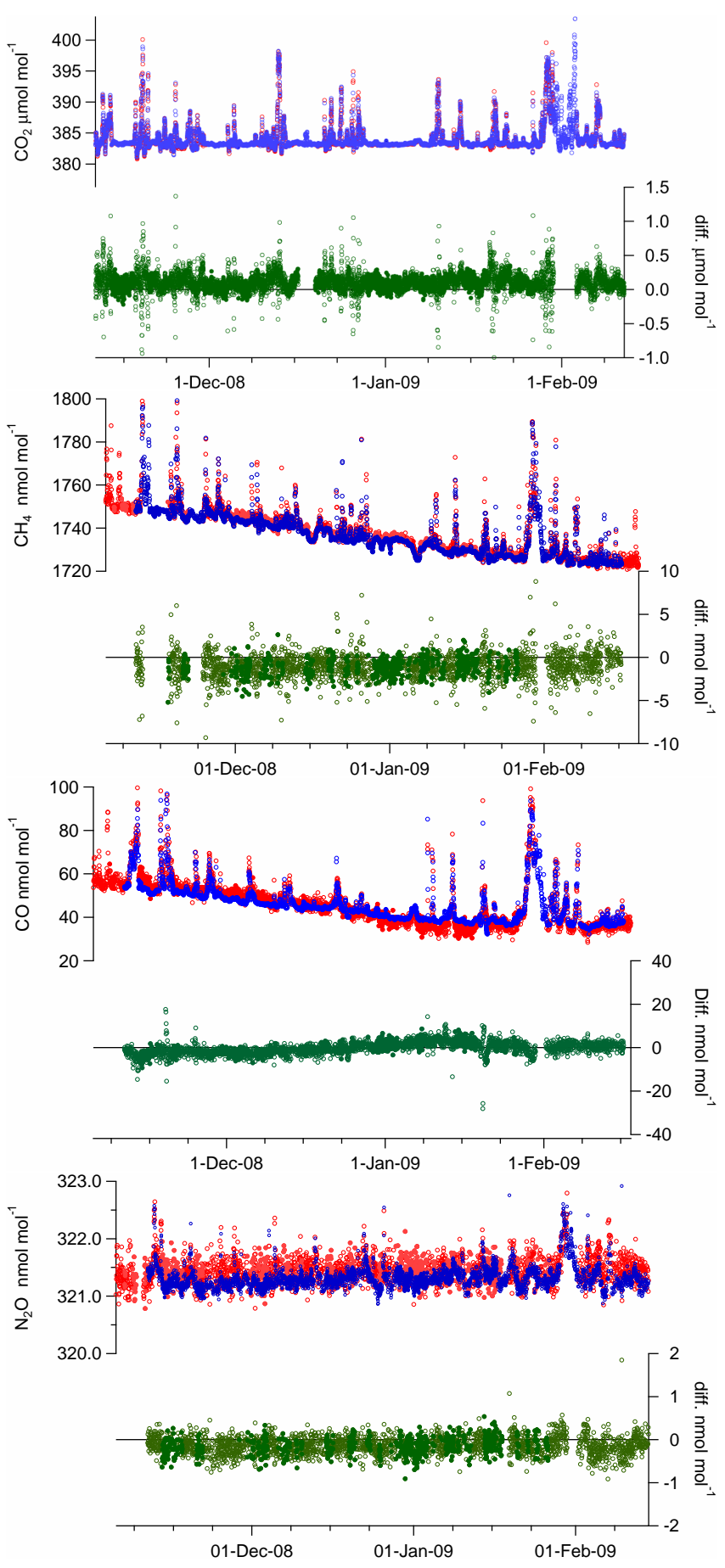

Fig. 8. Comparisons of FTIR measurements over a 3-month campaign at Cape Grim with LoFlo $\left(\mathrm{CO}_{2}\right)$ and AGAGE $\left(\mathrm{CH}_{4}, \mathrm{CO}\right.$, $\mathrm{N}_{2} \mathrm{O}$ ) GC measurements. Red: LoFlo/AGAGE. Blue: FTIR. Upper panels: time-coincident measurements. Lower panels: difference. Full circles represent baseline air periods, open circles non-baseline conditions. From (Griffith et al., 2011) with updates to AGAGE CO data calibration (see text for details). 


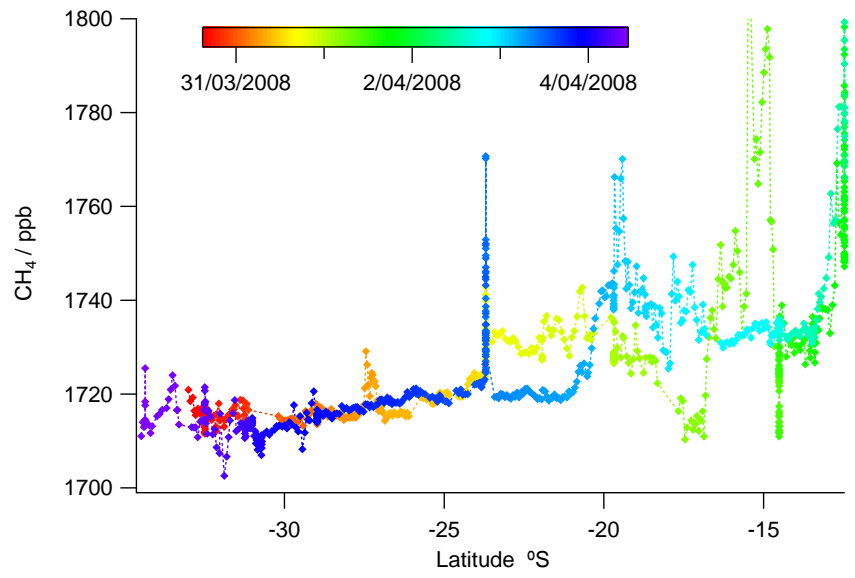

Fig. 9. Measurements of $\mathrm{CH}_{4}$ along a N-S transect aboard the Ghan train from Adelaide $\left(34^{\circ} \mathrm{S}\right)$ to Darwin $\left(12^{\circ} \mathrm{S}\right)$, March-April 2008. Figure adapted from (Deutscher et al., 2010), see text for summary.

the FTIR is more precise for each species. Calibration biases were less than the scatter in the AGAGE data.

\subsection{Mobile platforms}

The FTIR analyser is portable, robust and automated, and well suited to field applications. We have made FTIR measurements on eight $\mathrm{N}-\mathrm{S}$ transects of the Australian continent between Adelaide $\left(34^{\circ} \mathrm{S}\right)$ and Darwin $\left(12^{\circ} \mathrm{S}\right)$ onboard the Ghan train since 2008 (Deutscher et al., 2010). For these measurements the analyser is mounted in a nonairconditioned luggage van and draws air from an inlet on the side of the train. Figure 9 illustrates results for $\mathrm{CH}_{4}$ during the late wet season of 2008, covering 6 days in which the train travels from Adelaide in the south to Darwin in the north and returns. Although the train has diesel locomotives, there is no evidence for $\mathrm{CH}_{4}$ emissions from the engines. The observed $\mathrm{CH}_{4}$ mole fractions are distinctly different in three regions: variable in the agricultural and more populated southern section south of $30^{\circ} \mathrm{S}$; low variability and a distinct latitudinal gradient through the arid and unpopulated centre of the continent; and large, irregular enhancements north of $23^{\circ} \mathrm{S}$ affected by high seasonal monsoonal rainfall. Spikes at $23^{\circ} \mathrm{S}, 14^{\circ} \mathrm{S}$ and $12^{\circ} \mathrm{S}$ coincide with long pauses at $\mathrm{Al}-$ ice Springs, Katherine and Darwin, respectively, where urban emissions are sampled. The enhanced $\mathrm{CH}_{4}$ concentrations are attributed mostly to ephemeral emissions from wetlands and are being used to improve methane budgets in the Australian region (Deutscher et al., 2010; Fraser et al., 2011).

\subsection{Point source emissions detection}

The detection, location and quantification of leaks from potential carbon capture and storage (CCS) sites is of paramount importance for assessing the effectiveness of CCS technology for removing $\mathrm{CO}_{2}$ from the atmosphere. In an
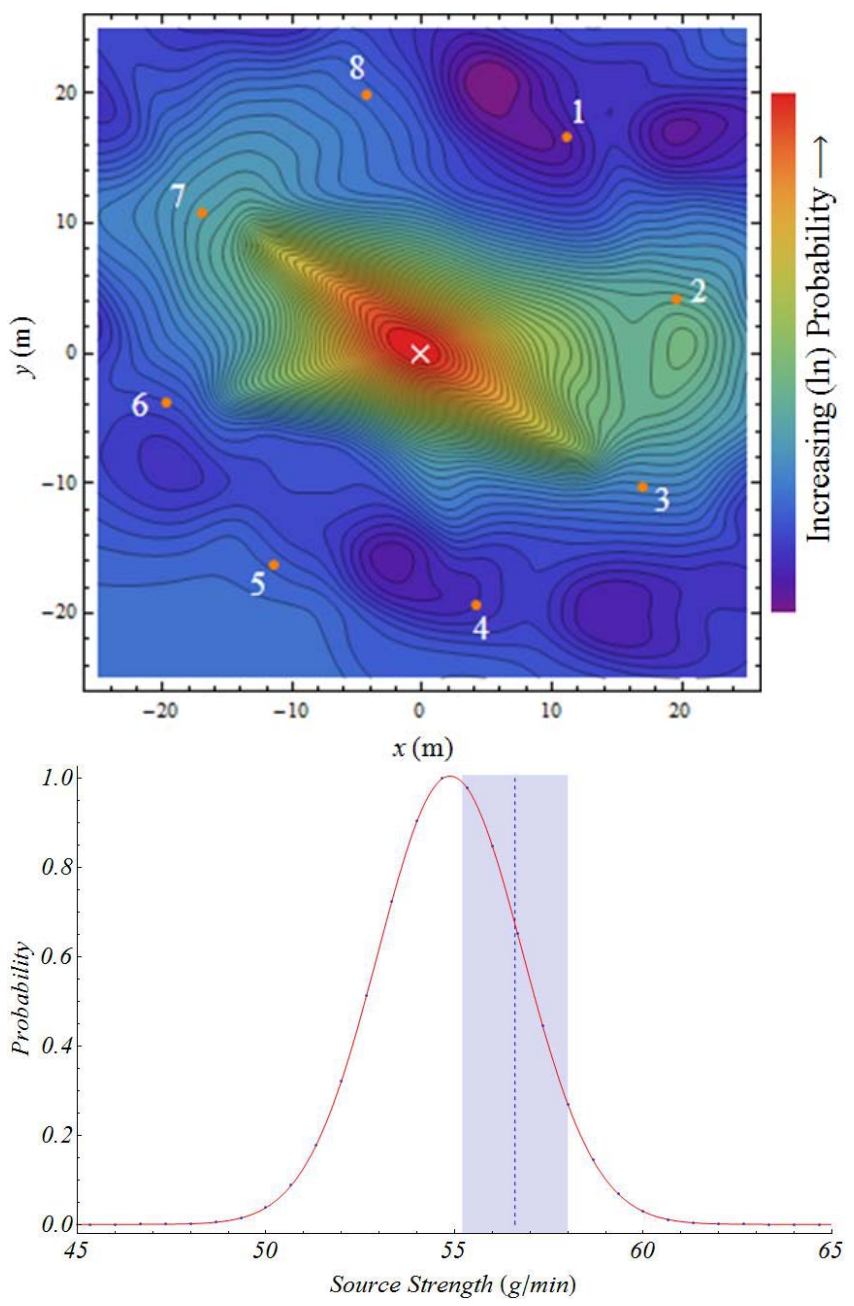

Fig. 10. Result of the FTIR-tomography detection of a $\mathrm{CO}_{2}$ point source release in a $50 \times 50 \mathrm{~m}$ area. In the upper frame, $\mathrm{x}$ marks the actual point location $(0,0 \mathrm{~m})$ from where $\mathrm{CO}_{2}$ and $\mathrm{N}_{2} \mathrm{O}$ were released, and 1-8 mark the locations of the sampling points for the FTIR analyser. The contours plot the a posteriori probability for the source point location determined from the atmospheric measurements $(-0.5,0.5 \mathrm{~m})$. The lower plot shows the known release rate $\left(56.7 \pm 0.8 \mathrm{~g} \mathrm{~min}^{-1}\right)$ and the a posterior probability determined from the measurements $\left(54.9 \pm 4(1 \sigma) \mathrm{g} \mathrm{min}^{-1}\right)$. Figure from Humphries et al. (2012), Fig. 5.

experiment to assess the possibility of remotely detecting such a leak through atmospheric measurements, Humphries et al. (2012) combined FTIR measurements with a novel tomographic analysis to locate and quantify a point source release of $\mathrm{CO}_{2}$ and $\mathrm{N}_{2} \mathrm{O}$ in a flat, homogeneous landscape. Using both $\mathrm{CO}_{2}$ and $\mathrm{N}_{2} \mathrm{O}$ simultaneously enabled the effect of background variability on the source retrieval to be assessed, since the background of $\mathrm{CO}_{2}$ is highly variable while that of $\mathrm{N}_{2} \mathrm{O}$ is not. The point source was located within a $50 \mathrm{~m}$ circle of 8 sampling points in a bare soil paddock. The sampling points were sequentially sampled and analysed by a common 


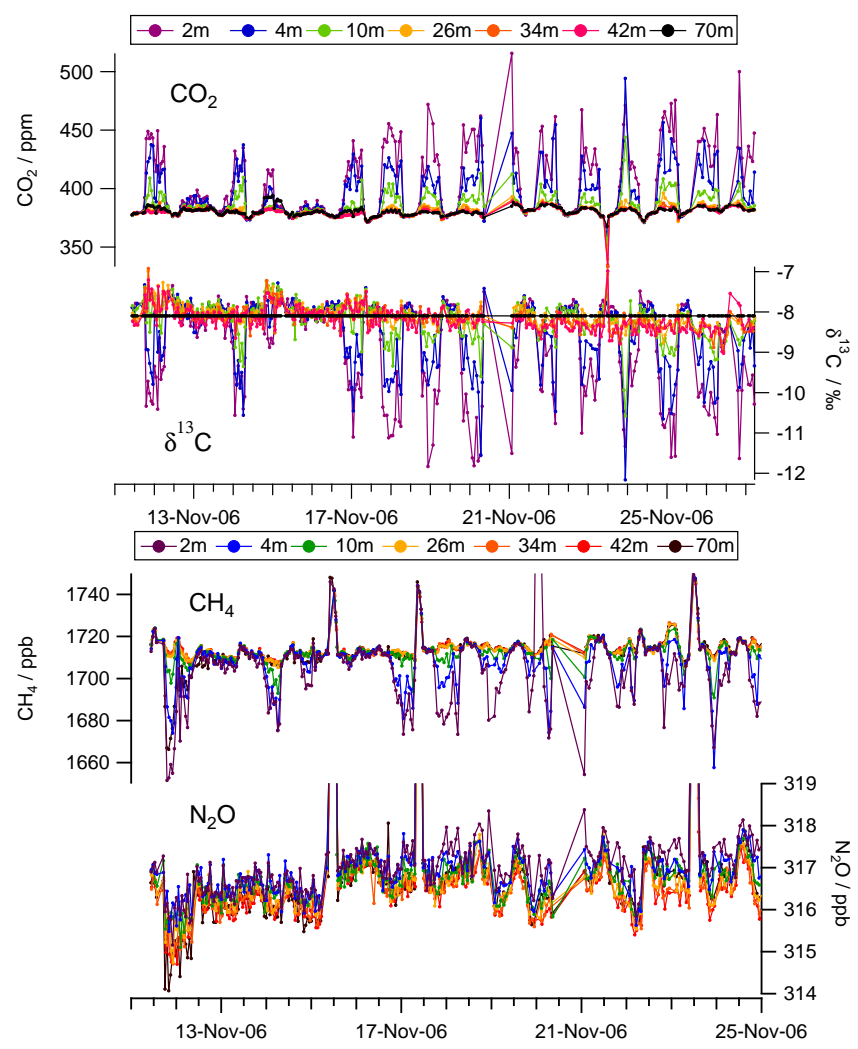

Fig. 11. Time series of (a) $\mathrm{CO}_{2}$ and $\delta^{13} \mathrm{C}$ in $\mathrm{CO}_{2}$ and (b) $\mathrm{CH}_{4}$ and $\mathrm{N}_{2} \mathrm{O}$ during a 3-week campaign at the Ozflux tower site near Tumbarumba, SE Australia, in November 2006. Seven-point vertical profiles of each species from $2-70 \mathrm{~m}$ were measured every $30 \mathrm{~min}$; colours represent measurements at heights above the surface shown in the legend. The top of the forest canopy is approx. $40 \mathrm{~m}$ above the surface.

FTIR analyser every 30 min continuously for several months, building up a catalogue of atmospheric concentrations at the 8 sampling points under a range of wind speeds and directions. A Bayesian analysis of the concentration and wind data was used to "find" the location and emission strength for each gas without detailed prior knowledge of either location or emission strength. Figure 10 shows the results of the analysis for the $\mathrm{CO}_{2}$ release. The analysis located the correct position of the release within $0.7 \mathrm{~m}$ and the strength within $4 \%$. Similar results were obtained for the $\mathrm{N}_{2} \mathrm{O}$ release. The FTIR analyser allowed the continuous autonomous operation of the sampling system for $\mathrm{CO}_{2}, \mathrm{~N}_{2} \mathrm{O}, \mathrm{CH}_{4}$ and $\mathrm{CO}$ over several months.

\subsection{Tower profile and flux measurements}

Vertical profiles of trace gas concentrations measured from tall towers and flux towers probe boundary layer mixing processes and trace gas exchange between the atmosphere, surface and plant/forest communities. The Australian Ozflux tower at Tumbarumba (Leuning et al., 2005) is situated in

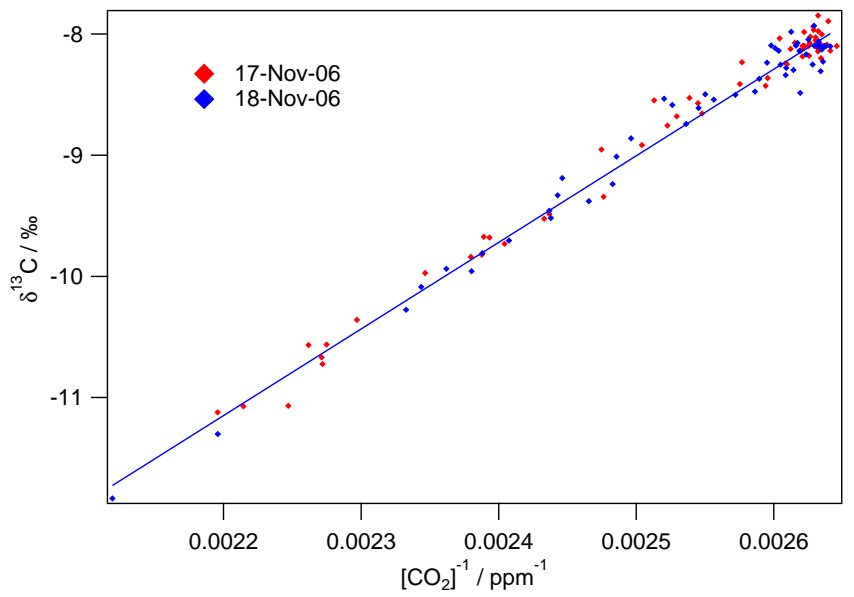

Fig. 12. Keeling plot of $\delta^{13} \mathrm{C}$ vs. $1 /\left[\mathrm{CO}_{2}\right]$ for two nights drawn from the data shown in Fig. 11. The mean intercept is $-26.8 \pm 0.4 \%$, indicative of respiration from the dominant $\mathrm{C} 3$ plants in the forest.

a mature eucalypt forest in SE Australia to investigate the exchanges of energy, water and carbon in this representative biome. The tower is $70 \mathrm{~m}$ high and extends above the canopy top, which is $\sim 40 \mathrm{~m}$ above ground level. In November 2006 we operated two FTIR analysers at the Ozflux tower over a 3week campaign, one sampling dried air for precise trace gas measurements, and one sampling undried air for stable water vapour isotope analysis. Seven inlets on the tower from 2 to $70 \mathrm{~m}$ above ground were sampled sequentially by both FTIR analysers every $30 \mathrm{~min}$ to provide vertical profiles of trace gases, $\delta^{13} \mathrm{C}$ in $\mathrm{CO}_{2}$ and $\delta \mathrm{D}$ in water vapour. The general intent of the campaign was to use vertical profiles of carbon and water isotopic compositions to partition water vapour between evaporation and transpiration, and $\mathrm{CO}_{2}$ between photosynthetic uptake and release by respiration. The campaign setup and water vapour isotope analysis have been described in detail elsewhere (Haverd et al., 2011). Time series of trace gases and $\delta^{13} \mathrm{C}$ are shown in Fig. 11. For $\mathrm{CO}_{2}$ and $\delta^{13} \mathrm{C}$ in $\mathrm{CO}_{2}$ (Fig. 11a) strong vertical gradients are observed in the canopy at night when canopy turbulence is low, but above the canopy the air is generally better mixed and gradients are much smaller. There is strong anti-correlation between $\mathrm{CO}_{2}$ and $\delta^{13} \mathrm{C}$ because the added respired $\mathrm{CO}_{2}$ is depleted in ${ }^{13} \mathrm{C}$. Figure 12 shows a typical Keeling plot of data collected over two nights; the y-intercept is $-26.8 \%$ o $( \pm 0.4 \%$ o $1 \sigma$ random uncertainty), consistent with respiration from the predominantly $\mathrm{C} 3$ plants that dominate this forest. However during daytime, when canopy turbulence and boundary layer mixing is stronger, the air is well mixed in and above the canopy and vertical gradients are smoothed out, making the determination of partitioning from isotopic profiles during daytime impractical. Figure $11 \mathrm{~b}$ shows vertical profile data for $\mathrm{CH}_{4}$ and $\mathrm{N}_{2} \mathrm{O}$, indicating clear uptake of $\mathrm{CH}_{4}$ at the surface (decreasing mole fractions near the ground), and barely detectable $\mathrm{N}_{2} \mathrm{O}$ emission (increasing mole fractions near the ground). 
Table 4. Approximate minimum detectable fluxes achievable with the FTIR analyser using the flux gradient technique under typical turbulent diffusion conditions: diffusion coefficient $0.1-0.2 \mathrm{~m}^{2} \mathrm{~s}^{-1}$, vertical gradient scale $\sim 1 \mathrm{~m}$.

\begin{tabular}{lll}
\hline & $\begin{array}{l}\text { Gradient } \\
\text { measurement precision }\end{array}$ & $\begin{array}{l}\text { Minimum } \\
\text { detectable flux }\end{array}$ \\
\hline $\mathrm{CO}_{2}$ & $0.1 \mu \mathrm{mol} \mathrm{mol}^{-1}$ & $0.04 \mathrm{mg} \mathrm{CO}_{2} \mathrm{~m}^{-2} \mathrm{~s}^{-1}$ \\
$\mathrm{~N}_{2} \mathrm{O}$ & $0.1 \mu \mathrm{mol} \mathrm{mol}^{-1}$ & $20 \mathrm{ngN} \mathrm{m}^{-2} \mathrm{~s}^{-1}$ \\
$\mathrm{CH}_{4}$ & $0.2 \mu \mathrm{mol} \mathrm{mol}^{-1}$ & $30 \mathrm{ng} \mathrm{CH}_{4} \mathrm{~m}^{-2} \mathrm{~s}^{-1}$ \\
\hline
\end{tabular}

Vertical gradients of trace gas concentrations can be used to calculate surface exchange fluxes if the turbulent diffusion can be quantified (e.g. Monteith and Unsworth, 1990). This technique was not practical in the forest environment, where turbulence within the canopy was high during the day and concentration gradients were small, or gradients were high at night but turbulence was suppressed. Flux gradient measurements are suited to agricultural environments above a uniform surface such as grass or crop. Here the high precision of the FTIR analyser is well suited to measurement of the small concentration gradients that exist. An early application to agricultural flux gradient measurements was able to quantify $\mathrm{CO}_{2}$ fluxes, but was not sufficiently precise for background $\mathrm{N}_{2} \mathrm{O}$ or $\mathrm{CH}_{4}$ fluxes except following rain when $\mathrm{N}_{2} \mathrm{O}$ emissions are enhanced (Griffith et al., 2002). Based on the Fick's Law relationship between flux and concentration gradient

$F=K(z) \frac{\partial C}{\partial z}$,

where $F=$ flux, $K=$ diffusion constant, $z=$ height and $C=$ concentration. With the measurement precisions described in Table 1, a typical turbulent diffusion constant of $0.1-0.2 \mathrm{~m}^{2} \mathrm{~s}^{-1}$, and a vertical scale for measuring gradients of the order of $1 \mathrm{~m}$, Table 4 provides estimates of minimum detectable fluxes for the FTIR analyser using the flux gradient technique. Eddy accumulation methods such as Relaxed Eddy Accumulation (REA) or Disjunct Eddy Accumulation (DEA) allow more measurement time to achieve higher trace gas measurement precision, and hence improved flux detection limits. We have applied the FTIR analyser in both REA and DEA techniques, which will be reported in forthcoming publications.

\subsection{Chamber measurements}

Micrometeorological flux measurement techniques are usually not able to resolve background fluxes of methane, nitrous oxide and trace gases other than $\mathrm{CO}_{2}$ because the small vertical gradients cannot be resolved with sufficient speed or precision by existing measurement techniques. In many cases, chamber measurements offer the only feasible method to estimate small fluxes, despite their limitations (e.g. site inhomogeneity and disturbance, microclimate perturbation) (Livingstone and Hutchinson, 1995). The FTIR analyser coupled to automated surface flux chambers provides a useful technique for greenhouse gas exchange measurements at the Earth's surface with several advantages:

- Simultaneous measurement of greenhouse gases $\mathrm{CO}_{2}$, $\mathrm{CH}_{4}$ and $\mathrm{N}_{2} \mathrm{O}$, as well as $\mathrm{CO}$ and $\delta^{13} \mathrm{C}$ in $\mathrm{CO}_{2}$

- High precision enabling the measurement of small fluxes

- Continuous measurements with 1 min averaging time or better, allowing assessment of the linearity of concentration changes and hence chamber leakage or other secondary processes occurring in the chamber

- Continuous fully automated operation

- The isotopic specificity of FTIR analysis allows the option to include isotopic labelling to elucidate the mechanisms of trace gas emissions.

We have carried out several FTIR-chamber flux studies in a variety of agricultural and natural settings. A fully automated system has operated continuously since 2004 measuring $\mathrm{N}_{2} \mathrm{O}$ fluxes from irrigated and non-irrigated pasture in Victoria, Australia (Kelly et al., 2008), and another system was deployed over a complete sugar cane growth cycle in northern Australia (Denmead et al., 2010). Both studies were based on earlier FTIR systems but provided continuous measurements over periods of months to years.

Here we briefly describe two current examples of chamber flux measurements with the FTIR analyser - full details will be published elsewhere. The Quasom field experiment at the Max Planck Institute for Biogeochemistry in Jena, Germany, (https://www.bgc-jena.mpg.de/bgp/index. php/Main/QuasomFieldExperiment) investigates the cycling of carbon through an entire growing cycle of an annual crop by measurements of all carbon pools and fluxes, including isotopic ${ }^{13} \mathrm{C}$ labelling and discrimination measurements. The FTIR analyser is coupled to 12 soil flux chambers in the field experiment and sequentially samples air from the chambers as each goes through a closure cycle. The sampled air is recirculated back to the chambers. The system has operated continuously since June 2011, with a 1-min measurementaveraging time and typically ninety 15 -min chamber closures per day. The ${ }^{13} \mathrm{CO}_{2}$ isotopic measurements were calibrated using the procedures described in Sect. 3, based on measurements of whole air reference gases provided by MPI-BGC. Results agree well for both absolute and empirical calibration methods, with $1 \sigma$ precision of better than $0.1 \%$.

Figure 13 illustrates trace gas measurements from a sequence of closures of seven individual chambers, made in the evening when there is no photosynthetic $\mathrm{CO}_{2}$ uptake. Individual chambers show considerable variability, but all are sources for $\mathrm{CO}_{2}$ and $\mathrm{N}_{2} \mathrm{O}$, sinks for $\mathrm{CO}$, and show complex 


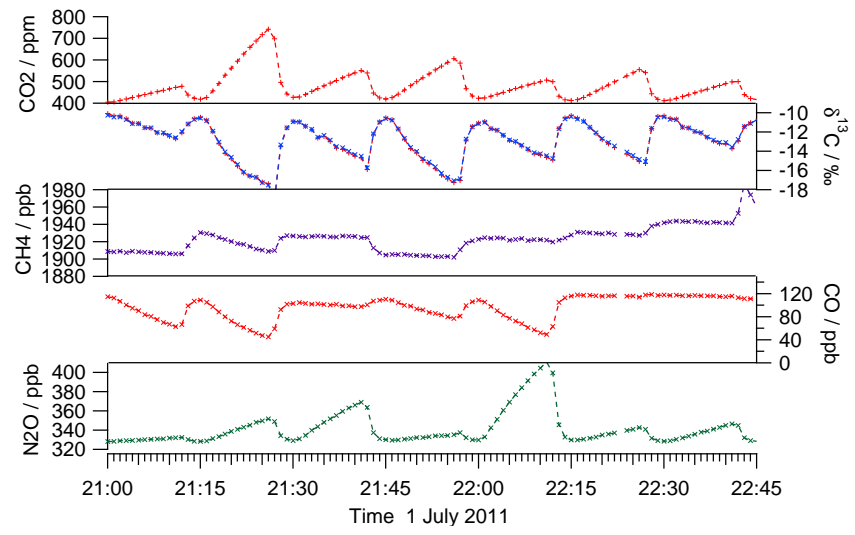

Fig. 13. Time sequence of mole fractions of $\mathrm{CO}_{2}, \mathrm{CH}_{4}, \mathrm{~N}_{2} \mathrm{O}, \mathrm{CO}$ and $\delta^{13} \mathrm{C}$ in $\mathrm{CO}_{2}$ measurements from seven sequential chamber closures in the Quasom experiment, 1 July 2011. See text for details.

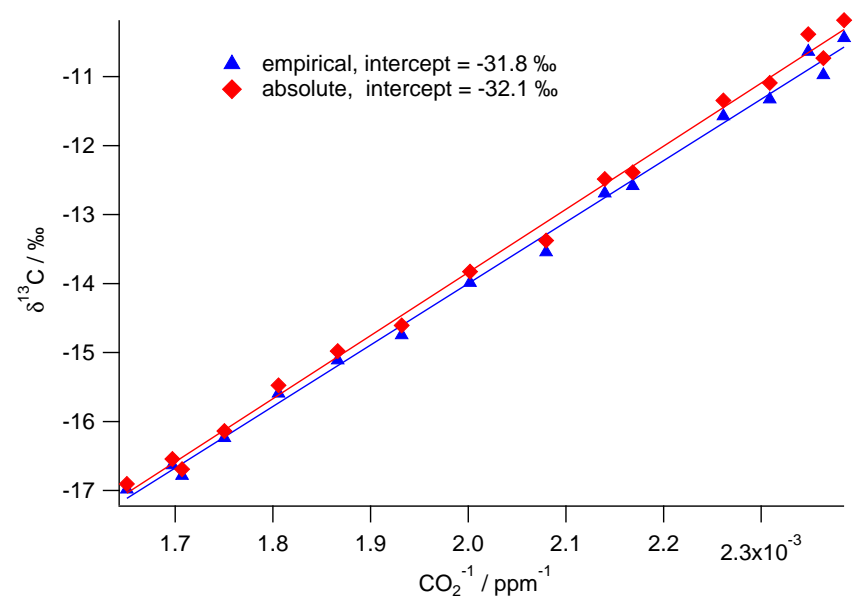

Fig. 14. Keeling plot of $\delta^{13} \mathrm{C}$ vs. $1 / \chi_{\mathrm{CO}_{2}}$ for a typical single chamber closure from the data of Fig. 13. The two plots are derived from the absolute and empirical $\delta^{13} \mathrm{C}$ calibration methods described in Sect. 3 .

behaviour for $\mathrm{CH}_{4} \cdot \mathrm{CO}_{2}$ emissions correlate with decreasing $\delta^{13} \mathrm{C}$ because the respired $\mathrm{CO}_{2}$ is depleted in ${ }^{13} \mathrm{C}$. Figure 14 shows a typical night-time Keeling plot of $\delta^{13} \mathrm{C}$ vs. $1 /\left(\mathrm{CO}_{2}\right.$ mole fraction) from a single chamber closure. The $\delta^{13} \mathrm{C}$ signature of the respired $\mathrm{CO}_{2}$ in the chamber is equal to the $\mathrm{y}$ intercept of the plots, -31.8 and $-32.1 \%$ o $( \pm 0.3 \%$ o $1 \sigma$ random uncertainty) for the empirical and absolute calibrations, respectively.

The second example of chamber flux measurements includes novel measurements of $\mathrm{N}_{2} \mathrm{O}$ isotopologues in the field (Phillips et al., 2012). Fluxes of ${ }^{14} \mathrm{~N}^{14} \mathrm{NO},{ }^{14} \mathrm{~N}^{15} \mathrm{NO}$, ${ }^{15} \mathrm{~N}^{14} \mathrm{NO}$ and ${ }^{15} \mathrm{~N}^{15} \mathrm{NO}$ were measured pre- and postaddition of ${ }^{15} \mathrm{~N}$ labelled substrate (potassium nitrate or urea) to the soil at a pasture site with a pneumatically-controlled, automated chamber system. Chambers were controlled and sampled sequentially by the FTIR analyser for $30 \mathrm{~min}$ each, with analysed air recirculated back to the chamber in a closed

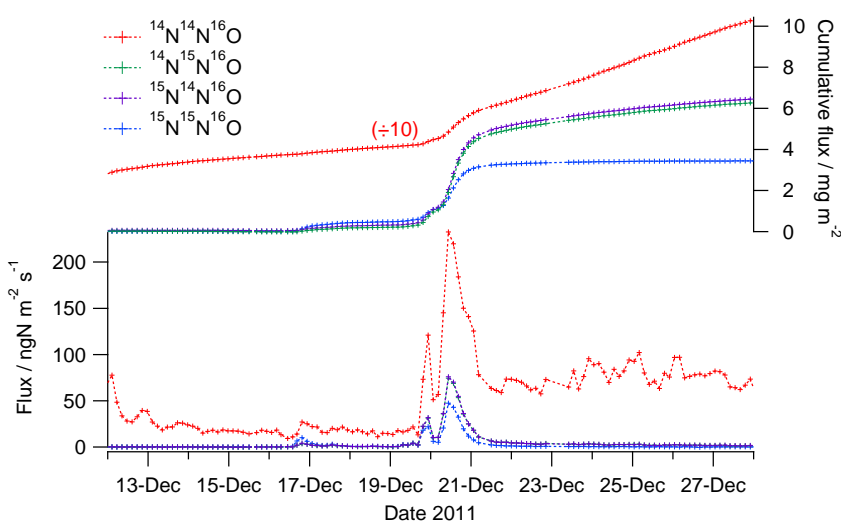

Fig. 15. $\mathrm{N}_{2} \mathrm{O}$ isotopologue emissions from pasture before and after addition of ${ }^{15} \mathrm{~N}$ as nitrate to the soil on 17 December 2011. Approximately $25 \mathrm{~mm}$ of rainfall fell on 20-21 December 2011. See text for further detail.

loop. Each chamber closed for $18 \mathrm{~min}$ out of the $30 \mathrm{~min}$ cycle and spectra were measured continuously with 1-min averaging time. Isotopologue amounts were determined by analysis of a spectral window near $2200 \mathrm{~cm}^{-1}$ in the strong $\nu_{3}$ band of $\mathrm{N}_{2} \mathrm{O}$. A total of 40 flux measurements (chamber closures) were collected each day from the five chambers between 1 December 2011 and 30 January 2012. Four chambers received ${ }^{15} \mathrm{~N}$ in solution and one chamber received water only. Only ${ }^{14} \mathrm{~N}^{14} \mathrm{NO}$ was detected for the water-only chamber; ${ }^{15} \mathrm{~N}$ isotopologues in natural abundance were below quantification limits. All four isotopologues were quantified with better than $1 \mathrm{nmol} \mathrm{mol}^{-1}$ precision for the four chambers dosed with ${ }^{15} \mathrm{~N}$. Figure 15 shows the instantaneous and cumulative fluxes of all $\mathrm{N}_{2} \mathrm{O}$ isotopologues from 4 days before ${ }^{15} \mathrm{~N}$ addition to 8 days after. ${ }^{15} \mathrm{~N}$-labelled $\mathrm{N}_{2} \mathrm{O}$ emissions decreased to near-zero levels after 8 days, while emissions of unlabelled $\mathrm{N}_{2} \mathrm{O}$ continued from the unlabelled soil nitrogen pool. This experiment enabled the measurement of additional $\mathrm{N}_{2} \mathrm{O}$ emitted due to nitrogen addition independent of the background $\mathrm{N}_{2} \mathrm{O}$ emission flux. Approximately 1-2\% of the added $\mathrm{N}$ was emitted as $\mathrm{N}_{2} \mathrm{O}$.

\section{Conclusions}

The FTIR trace gas analyser provides simultaneous, continuous, high precision analysis of the atmospheric trace gases $\mathrm{CO}_{2}, \mathrm{CH}_{4}$ and $\mathrm{N}_{2} \mathrm{O}$ and $\mathrm{CO}$ in air. A $1-5$ min averaging time is sufficient to achieve repeatability meeting GAW measurement compatibility targets for clean air measurements, and with careful calibration the accuracy is of similar magnitude (Hammer et al., 2012). In addition, parallel measurements of $\delta^{13} \mathrm{C}$ in $\mathrm{CO}_{2}$ from the same air samples with precision only slightly less than GAW targets are obtained. The analyser is suited to a wide range of applications in atmospheric trace gas measurements, including composition monitoring 
at clean air baseline stations and on mobile platforms, micrometeorological and chamber flux measurements, and isotopic measurements of atmospheric trace gases.

Acknowledgements. We gratefully acknowledge the contributions, comments and feedback from many colleagues over the years of development and application of the FTIR analyser. These include Dan Smale, Vanessa Sherlock, Thorsten Warneke, Katinka Petersen for feedback on the instrument operation and performance, Grant Kassell and other staff of Ecotech Pty Ltd for developments in the commercialisation of the analyser, many staff of CSIRO and the Cape Grim Baseline Air Pollution Station for measurements at Cape Grim, GASLAB and the Ozflux tower site, Marion Schrumpf and Armin Jordan for measurements at the Quasom site in Jena, and Rebecca Phillips for collaboration in the $\mathrm{N}_{2} \mathrm{O}$ isotope chamber studies.

Edited by: O. Tarasova

\section{References}

Allan, D.: Statistics of atomic frequency standards, Proc. IEEE, 54, 221-230, 1966.

Anderson, R. J. and Griffiths, P. R.: Errors in absorbance measurements in infrared Fourier transform spectrometry because of limited instrument resolution, Anal. Chem., 47, 2339-2347, 1975.

Chen, H., Winderlich, J., Gerbig, C., Hoefer, A., Rella, C. W., Crosson, E. R., Van Pelt, A. D., Steinbach, J., Kolle, O., Beck, V., Daube, B. C., Gottlieb, E. W., Chow, V. Y., Santoni, G. W., and Wofsy, S. C.: High-accuracy continuous airborne measurements of greenhouse gases $\left(\mathrm{CO}_{2}\right.$ and $\left.\mathrm{CH}_{4}\right)$ using the cavity ringdown spectroscopy (CRDS) technique, Atmos. Meas. Tech., 3, 375-386, doi:10.5194/amt-3-375-2010, 2010.

Cohen, E. R., Cvitas, T., Frey, J. G., Holmstroem, B., Kuchitsu, K., Marquardt, R., Mills, I., Pavese, F., Quack, M., Stohner, J., Strauss, H. L., Takami, M., and Thor, A. J.: Quantities, Units and Symbols in Physical Chemistry, IUPAC, RSC Publishing, Cambridge, 2007.

Coplen, T. B.: Explanatory glossary of terms used in expression of relative isotope ratios and gas ratios, IUPAC, 27, available at: http://old.iupac.org/reports/provisional/abstract08/ coplen_prs.pdf, 2008.

Davis, S. P., Abrams, M. C., and Brault, J. W.: Fourier Transform Spectrometry, Academic Press, 2001.

Denmead, O. T., Macdonald, B. C. T., Bryant, G., Naylor, T., Wilson, S., Griffith, D. W. T., Wang, W. J., Salter, B., White, I., and Moody, P. W.: Emissions of methane and nitrous oxide from Australian sugarcane soils, Agric. For. Meteorol., 150, 748-756, doi:10.1016/j.agrformet.2009.06.018, 2010.

Deutscher, N. M., Griffith, D. W. T., Paton-Walsh, C., and Borah, R.: Train-borne measurements of tropical methane enhancements from ephemeral wetlands in Australia., J. Geophys. Res., 115, D15304, doi:15310.11029/12009JD013151., 2010.

Esler, M. B., Griffith, D. W. T., Wilson, S. R., and Steele, L. P.: Precision trace gas analysis by FT-IR spectroscopy 1 . Simultaneous analysis of $\mathrm{CO}_{2}, \mathrm{CH}_{4}, \mathrm{~N}_{2} \mathrm{O}$ and $\mathrm{CO}$ in air, Anal. Chem., 72, 206-215, 2000a.
Esler, M. B., Griffith, D. W. T., Wilson, S. R., and Steele, L. P.: Precision trace gas analysis by FT-IR spectroscopy 2 . The ${ }^{13} \mathrm{C} /{ }^{12} \mathrm{C}$ isotope ratio of $\mathrm{CO}_{2}$, Anal. Chem., 72, 216-221, 2000b.

Francey, R. J., Trudinger, C. M., Schoot, M. v. d., Krummel, P. B., Steele, L. P., and Langenfelds, R. L.: Differences between trends in atmospheric $\mathrm{CO}_{2}$ and the reported trends in anthropogenic $\mathrm{CO}_{2}$ emissions, Tellus, 62B, 316-328, doi:10.1111/j.16000889.2010.00472.x, 2010.

Fraser, A., Miller, C. C., Palmer, P. I., Deutscher, N. M., Jones, N. B., and Griffith, D. W. T.: The Australian methane budget: New insights from surface and train-borne measurements, J. Geophys. Res., 116, D20306, doi:10.1029/2011JD015964, 2011.

GAW: Report no. 194. 15th WMO/IAEA Meeting of Experts on Carbon Dioxide, Other Greenhouse Gases and Related Tracers Measurement Techniques, GenevaWMO/TD-No. 1553, 2011.

Griffith, D. W. T.: Synthetic calibration and quantitative analysis of gas phase infrared spectra, Appl. Spectrosc., 50, 59-70, 1996.

Griffith, D. W. T.: FTIR measurements of atmospheric trace gases and their fluxes, in: Handbook of vibrational spectroscopy, edited by: Chalmers, J. M. and Griffiths, P. R., John Wiley \& Sons, 2823-2841, 2002.

Griffith, D. W. T. and Jamie, I. M.: FTIR spectrometry in atmospheric and trace gas analysis, in: Encyclopedia of Analytical Chemistry, edited by: Meyers, R. A., Wiley, 1979-2007, 2000.

Griffith, D. W. T., Leuning, R., Denmead, O. T., and Jamie, I. M.: Air-Land Exchanges of $\mathrm{CO}_{2}, \mathrm{CH}_{4}$ and $\mathrm{N}_{2} \mathrm{O}$ measured by FTIR Spectroscopy and Micrometeorological Techniques, Atmos. Environ., 38, 1833-1842, 2002.

Griffith, D. W. T., Deutscher, N., Krummel, P., Fraser, P., Steele, P., Schoot, M. v. d., and Allison, C.: The UoW FTIR trace gas analyser: comparison with LoFlo, AGAGE and tank measurements at CApe Grim and GASLAB, in: Baseline Atmospheric Program (Australia) 2007-2008, edited by: Derek, P. K. a. N., CSIRO, Melbourne, availaable at: http://www.bom.gov.au/inside/cgbaps/ baseline.shtml, 2011.

Griffiths, P. R. and de Haseth, J. A.: Fourier Transform Infrared Spectrometry, 2nd Edn., Wiley, 2007.

Haaland, D. M.: Methods to include Beer's Law non-linearities in quantitative spectral analysis, in: Computerised Quantitative Infrared Analysis, ASTM-STP-934, edited by: McClure, G. L., American Society for Testing and Materials, Philadelphia, 78-94, 1987.

Hammer, S., Griffith, D. W. T., Konrad, G., Vardag, S., Caldow, C., and Levin, I.: Assessment of a multi-species in-situ FTIR for precise atmospheric greenhouse gas observations, Atmos. Meas. Tech. Discuss., 5, 3645-3692, doi:10.5194/amtd-5-3645-2012, 2012.

Haverd, V., Cuntz, M., Griffith, D., Keitel, C., Tadros, C., and Twining, J.: Measured deuterium in water vapour concentration does not improve the constraint on the partitioning of evapotranspiration in a tall forest canopy, as estimated using a soil vegetation atmosphere transfer model, Agric. For. Meteorol., 151, 645-654, 2011.

Hofmann, D. J., Butler, J. H., Dlugokencky, E. J., Elkins, J. W., Masarie, K., Montzka, S. A., and Tans, P.: The role of carbon dioxide in climate forcing from 1979 to 2004: Introduction to the Annual Greenhouse Gas Index, Tellus, 58B, 614-619, 2006.

Humphries, R., Jenkins, C., Leuning, R., Zegelin, S., Griffith, D., Caldow, C., Berko, H., and Feitz, A.: Atmospheric Tomography: 
A Bayesian Inversion Technique for Determining the Rate and Location of Fugitive Emissions, Environ. Sci. Technol., 46, 1739-1746, doi:10.1021/es202807s, 2012.

IPCC: Contribution of Working Group I to the Fourth Assessment Report of the Intergovernmental Panel on Climate Change, Geneva, 2007.

JCGM: Evaluation of measurement data - Guide to the expression of uncertainty in measurement (GUM), Joint Committee for Guides in Measurement - Working Group 1 (JCGM/WG1JCGM) 100:2008, 2008.

Johnson, T. J., Profeta, L. T. M., Sams, R. L., Griffith, D. W. T., and L.Yokelson, R.: An Infrared Spectral Database for Detection of Gases Emitted by Biomass Burning, Vib. Spectrosc., 53, 97-102, doi:10.1016/j.vibspec.2010.02.010, 2010.

Keeling, C. D., Whorf, T. P., Wahlen, M., and Plicht, J. v. d.: Interannual extremes in the rate of rise of atmospheric carbon dioxide since 1980, Nature, 375, 666-670, 1995.

Kelly, K. B., Phillips, F. A., and Baigent, R.: Impact of dicyandiamide application on nitrous oxide emissions from urine patches in northern Victoria, Australia, Aust. J. Exp. Agr., 48, 156-159, doi:10.1071/EA07251, 2008.

Langenfelds, R., Steele, P., Leist, M., Krummel, P. B., Spencer, D., and Howden, R.: Atmospheric methane, carbon dioxide, hydrogen, carbon monoxide, and nitrous oxide from Cape Grim flask air samples analysed by gas chromatography, in: Baseline Atmospheric Program (Australia) 2007-2008, edited by: Derek, N. and Krummel, P. B., Bureau of Meteorology and CSIRO Marine and Atmospheric Research, Melbourne, 62-66, http://www.bom.gov.au/inside/cgbaps/baseline.shtml, 2011.

Leuning, R., Cleugh, H. A., Zegelin, S. J., and Hughes, D.: Carbon and water fluxes over a temperate Eucalyptus forest and tropical wet/dry savanna in Australia: measurements and comparison with MODIS remote sensing estimates, Agric. For. Meteorol., $129,151-173,2005$

Livingstone, G. P. and Hutchinson, G. L.: Enclosure-based measurements of trace gas exchange: applications and sources of error, in: Biogenic Trace Gases: Measuring emissions from soil and water, edited by: Matson, P. A. and Harriss, R. C., Blackwell Science, 1995.

Loh, Z. M., Steele, L. P., Krummel, P. B., Schoot, M. v. d., Etheridge, D. M., Spencer, D. A., and Francey, R. J.: Linking Isotopologue Specific Measurements of $\mathrm{CO}_{2}$ to the Existing International Mole Fraction Scale, 15th WMO/IAEA Meeting of Experts on Carbon Dioxide, Other Greenhouse Gases and Related Tracers Measurement Techniques (WMO/GAW report no. 194), Jena, Germany, August 2009, 2011.

Monteith, J. L. and Unsworth, M. H.: Principles of Environmental Physics, Edward Arnold, London, 1990.

Parkes, S. D., Element, A., Griffith, D. W. T., Haverd, V., and Wilson, S. R.: An in-situ FTIR analyser for simultaneous real-time water vapour stable isotope and greenhouse gas measurements, Atmospheric Measurement Techniques, in preparation, 2012.

Phillips, R., Griffith, D. W. T., Dijkstra, F., Lugg, G., Lawrie, R., and Macdonald, B.: Continuous field measurement of $\mathrm{N}_{2} \mathrm{O}$ isotopologues using FTIR spectroscopy following ${ }^{15} \mathrm{~N}$ addition, American Geophysical Union Fall meeting, San Francisco, 2012,

Popa, M. E., Gloor, M., Manning, A. C., Jordan, A., Schultz, U., Haensel, F., Seifert, T., and Heimann, M.: Measurements of greenhouse gases and related tracers at Bialystok tall tower station in Poland, Atmos. Meas. Tech., 3, 407-427, doi:10.5194/amt-3-407-2010, 2010.

Press, W. H., Teukolsky, S. A., Vetterling, W. T., and Flannery, B. P.: Numerical Recipes, Cambridge University press, 1992.

Prinn, R. G., Weiss, R. F., Fraser, P. J., Simmonds, P. G., Cunnold, D. M., Alyea, F. N., O’Doherty, S., Salameh, P., Miller, B. R., Huang, J., Wang, R. H. J., D.E.Hartley, Harth, C., Steele, L. P., Sturrock, G., Midgley, P. M., and McCulloch, A.: A history of chemically and radiatively important gases in air deduced from ALE/GAGE/AGAGE, J. Geophys. Res., 105, 1775117792, 2000.

Ravishankara, A. R., Daniel, J. S., and Portmann, R. W.: Nitrous oxide $\left(\mathrm{N}_{2} \mathrm{O}\right)$ : the dominant ozone-depleting substance emitted in the 21st century, Science, 326, 123-125, 2009.

Rothman, L. S., Jacquemart, D., Barbe, A., Benner, D. C., Birk, M., Brown, L. R., Carleer, M. R., C. Chackerian, J., Chance, K., Dana, V., Devi, V. M., Flaud, J.-M., Gamache, R. R., Goldman, A., Hartmann, J.-M., Jucks, K. W., Maki, A. G., Mandin, J.-Y., Massie, S. T., Orphali, J., Perrin, A., Rinsland, C. P., Smith, M. A. H., Tennyson, J., Tolchenov, R. N., Toth, R. A., Auwera, J. V., Varanasi, P., and Wagner, G.: The HITRAN 2004 molecular spectroscopic database, J. Quant. Spectrosc. Ra., 96, 139-204, 2005.

Rothman, L. S., Gordon, I. E., Barbe, A., Benner, D. C., Bernath, P. E., Birk, M., Boudon, V., Brown, L. R., Campargue, A., Champion, J. P., Chance, K., Coudert, L. H., Dana, V., Devi, V. M., Fally, S., Flaud, J. M., Gamache, R. R., Goldman, A., Jacquemart, D., Kleiner, I., Lacome, N., Lafferty, W. J., Mandin, J. Y., Massie, S. T., Mikhailenko, S. N., Miller, C. E., Moazzen-Ahmadi, N., Naumenko, O. V., Nikitin, A. V., Orphal, J., Perevalov, V. I., Perrin, A., Predoi-Cross, A., Rinsland, C. P., Rotger, M., Simeckova, M., Smith, M. A. H., Sung, K., Tashkun, S. A., Tennyson, J., Toth, R. A., Vandaele, A. C., and Vander Auwera, J.: The HITRAN 2008 molecular spectroscopic database, J. Quant. Spectrosc. Ra., 110, 533-572, 2009.

Sharpe, S. W., Johnson, T. J., Sams, R. L., Chu, P. M., Rhoderick, G. C., and Johnson, P. A.: Gas phase databases for quantitative infrared spectroscopy, Appl. Spectrosc., 58, 1452-1461, 2004.

Smith, T. E. L., Wooster, M. J., Tattaris, M., and Griffith, D. W. T.: Absolute accuracy and sensitivity analysis of OP-FTIR retrievals of $\mathrm{CO}_{2}, \mathrm{CH}_{4}$ and $\mathrm{CO}$ over concentrations representative of "clean air" and "polluted plumes", Atmos. Meas. Tech., 4, 97 116, doi:10.5194/amt-4-97-2011, 2011.

Steele, L. P., Krummel, P., D, S., Rickard, C., Baly, S., Langenfelds, R., and Schoot, M. v. d.: Baseline carbon dioxide monitoring, in: Baseline Atmospheric Program (Australia) 2007-2008, edited by: Derek, N. and Krummel, P., Bureau of Meteorology and CSIRO Marine and Atmospheric Research, Melbourne, 5153, http://www.bom.gov.au/inside/cgbaps/baseline.shtml, 2011.

Tuzson, B., Henne, S., Brunner, D., Steinbacher, M., Mohn, J., Buchmann, B., and Emmenegger, L.: Continuous isotopic composition measurements of tropospheric $\mathrm{CO}_{2}$ at Jungfraujoch (3580 m a.s.1.), Switzerland: real-time observation of regional pollution events, Atmos. Chem. Phys., 11, 1685-1696, doi:10.5194/acp-11-1685-2011, 2011.

van der Laan, S., Neubert, R. E. M., and Meijer, H. A. J.: A single gas chromatograph for accurate atmospheric mixing ratio measurements of $\mathrm{CO}_{2}, \mathrm{CH}_{4}, \mathrm{~N}_{2} \mathrm{O}, \mathrm{SF}_{6}$ and $\mathrm{CO}$, Atmos. Meas. Tech., 2, 549-559, doi:10.5194/amt-2-549-2009, 2009. 
Vermeulen, A. T., Hensen, A., Popa, M. E., van den Bulk, W. C. M., and Jongejan, P. A. C.: Greenhouse gas observations from Cabauw Tall Tower (1992-2010), Atmos. Meas. Tech., 4, 617644, doi:10.5194/amt-4-617-2011, 2011.
Werle, P., Muecke, R., and Slemr, F.: The limits of signal averaging in trace gas monitoring by tunable diode laser absorption spectroscopy (TDLAS), Appl. Phys., B57, 131-139, 1993. 